\title{
Mineral chemistry of megacrysts and associated clinopyroxenite enclaves in the Calatrava volcanic field: crystallization processes in mantle magma chambers
}

\author{
C. Villaseca ${ }^{1,2}$ (I) $\cdot$ O. Dorado $^{1} \cdot$ D. Orejana ${ }^{1}$
}

Received: 28 June 2018 / Accepted: 29 January 2019

(c) Universidad Complutense de Madrid 2019

\begin{abstract}
Clinopyroxene, amphibole and phlogopite megacrysts appear in the crystal- and xenolith-rich pyroclastic deposits of the Cerro Pelado and the El Aprisco volcanoes (Calatrava volcanic field). These megacrysts display a similar composition to crystals forming clinopyroxenite and rare phlogopite-rich (glimmerite) enclaves. The host magmas are highly porphyritic, showing a complex population of mafic macrocrysts and phenocryst cores. Most of these crystals are chemically similar, suggesting that they constitute a cogenetic suite of phenocrystic origin. Geobarometric estimations indicate that megacrysts and enclaves represent high-P cumulates, mostly formed at about 12-16 kbar within the upper lithospheric mantle (35 to $55 \mathrm{~km}$ ). The compositional variability of the analyzed minerals indicates a differentiation process controlled by fractionation of olivine, clinopyroxene, amphibole and phlogopite. The crystallization of hydrous mafic minerals at mantle depths facilitated $\mathrm{CO}_{2}$ exsolution and subsequent boiling of the host magma, thus triggering the fragmentation of the semi-crystallized margin of the magma chamber and the excavation of mantle wall-rocks. This deep fragmentation could also explain the complex variety of crystals, enclaves and xenoliths dragged by the volcanic magmas. Two clinopyroxene types (green and colourless) have been found, both as antecrysts (macrocryst/phenocryst cores) and within enclaves. The coexistence of these clinopyroxenes within zoned crystals in clinopyroxenites suggests that they might be cognate, representing primitive and evolved products of a single fractionating magma. This study provides a model for the ascent of crystal- and xenolith-rich magmas that could be regarded in other alkaline volcanics carrying complex crystal cargos from the Cenozoic circum-Mediterranean area.
\end{abstract}

Keywords Mafic megacrysts · Clinopyroxenite $\cdot$ Glimmerite $\cdot$ Melilitite melt $\cdot$ Calatrava volcanic field $\cdot$ Alkaline circumMediterranean province

\section{Resumen}

Megacristales de clinopiroxeno, anfíbol y flogopita aparecen en los depósitos piroclásticos ricos en cristales, enclaves y xenolitos, de los volcanes de El Aprisco y Cerro Pelado (campo volcánico de Calatrava). Estos megacristales muestran una composición química similar a los cristales que forman los enclaves clinopiroxeníticos asociados, incluyendo los poco comunes enclaves ricos en flogopita (glimmeritas). El magma volcánico es de textura porfídica, mostrando una compleja población de fenocristales y macrocristales máficos, con núcleos residuales, que sugieren formen una suite cogenética con aquellos. Las estimaciones geobarométricas indican que los megacristales, así como los núcleos de fenocristales y los enclaves clinopiroxeníticos representan acumulados de alta presión, formados entre 12-16 kbar, en el manto litosférico superior (de 35 a $55 \mathrm{~km}$ ). La variabilidad composicional de estos minerales máficos apunta a un proceso de diferenciación controlado por la cristalización de olivino, clinopiroxeno, anfíbol y flogopita. La cristalización de minerales máficos hidratados en el manto facilitaría la exsolución de CO2 y la subsecuente ebullición del fundido, posibilitando la fragmentación de los márgenes semicristalinos de la cámara magmática y la excavación de la roca mantélica encajante. Esta fragmentación

Electronic supplementary material The online version of this article (https://doi.org/10.1007/s41513-019-00101-3) contains supplementary material, which is available to authorized users.

Extended author information available on the last page of the article 
profunda explicaría también la compleja variedad de cristales, enclaves y xenolitos atrapados por los magmas volcánicos. Se han encontrado dos tipos de clinopiroxenos (verde e incoloro) que aparecen como antecristales (núcleos de macrocristales/fenocristales) y también en los enclaves piroxeníticos. La coexistencia de ambos tipos de clinopiroxeno en los zonados cristalinos de las clinopyroxenitas sugiere que deben ser cogenéticos, representando precipitados de fundidos de distinto grado evolutivo, pero posiblemente de un mismo magma fraccionante. Este estudio propone un modelo de ascenso y origen de magmas ricos en cristales y xenolitos que puede ser útil para explicar otros tipos volcánicos que transportan complejos cargamentos de cristales profundos, como ocurre frecuentemente en la provincia volcánica circum-Mediterránea.

Palabras clave megacristales máficos $\cdot$ clinopyroxenita $\cdot$ glimmerita $\cdot$ fundidos melilitíticos $\cdot$ campo volcánico de Calatrava $\cdot$ provincia alcalina circum-Mediterránea

\section{Introduction}

The presence of mafic megacrysts and ultramafic xenoliths is a common feature in alkaline and ultralkaline volcanic rocks (e.g., Irving and Frey 1984; Praegel 1981; Jankovics et al. 2016). Although these xenoliths are usually peridotitic and represent mantle fragments removed during magma ascent, pyroxenites are not rare (e.g., Downes 2007). Pyroxenite enclaves have been interpreted as solid-state recycled subducted lithosphere (Allègre and Turcotte 1986), metasomatic products (Garrido and Bodinier 1999) or high pressure segregates (e.g., Wilshire and Shervais 1975; Bodinier et al. 1987; Wilkinson and Stolz 1997). In this latter case, it is typical the association of clinopyroxenite enclaves containing hydrous minerals with the equivalent megacrysts (clinopyroxene, amphibole and phlogopite) (e.g., Orejana et al. 2006 and references therein). The heterogeneous chemical composition shown by these mafic minerals is helpful to constrain the mechanisms operating within deep magma chambers (in either the lower crust or upper mantle). Fractionation, mixing and recharge with a more primitive melt determine the mineral texture and zoning, and can control the magma evolution and promote volcanic eruptions (e.g., Wiesmaier et al. 2011). These processes can occur at different pressures within a stepped magmatic system, to the point that the eventual volcanic rock can be a mixture of mafic minerals generated at different pressures and from different melts (e.g., Ubide et al. 2014).

The alkaline and ultralkaline volcanic rocks of the circum-Mediterranean Cenozoic igneous province carry such mafic megacrysts and enclaves, and numerous studies have focused on their interpretation with respect to the magmatic processes involved (e.g., Witt-Eickschen and Kramm 1998; Shaw and Eyzaguirre 2000; Jankovics et al. 2016) and the evolution of this anorogenic magmatism and the subcontinental lithospheric mantle (e.g., Lustrino and Wilson 2007).

In the Iberian Peninsula there are four main Cenozoic volcanic fields: Olot (NE), Calatrava (central), Levante (E) and Almeria (SE) (Fig. 1). The presence of clinopyroxene, amphibole and phlogopite megacrysts has been described in many volcanoes of the Calatrava field (e.g., Ancochea 1982;
Cebriá 1992). Their origin has been roughly explained as due to high-pressure crystallization from volatile-rich magmas produced by partial melting of a metasomatised mantle (Ancochea and Nixon 1987). The Morrón de Villamayor is different to other Calatrava volcanoes in carrying only anhydrous mafic macrocrysts $(<5 \mathrm{~mm})$, mainly zoned olivine, interpreted as the result of mixing of silica-undersaturated basic magmas in the upper lithospheric mantle (Lustrino et al. 2016). In the Olot volcanic field, anhydrous mafic megacrysts (clinopyroxene and olivine) within basanite magmas have been also described and interpreted as fragmented crystals (antecrysts) of earlier olivine clinopyroxenite cumulates from the magma-plumbing system (Galán et al. 2017).

The Neogene Calatrava volcanic field (CVF) comprises more than 200 monogenetic volcanic centres in an area of around $5500 \mathrm{~km}^{2}$ (Ancochea 1982; Fig. 1). Two volcanoes of the CVF have been sampled in this work due to the common presence of mafic megacrysts and enclaves in their pyroclastic deposits: the Cerro Pelado scoria cone (olivine nephelinite) and the El Aprisco maar (olivine melilitite), the latter also called Las Navas maar (Villaseca et al. 2010; Stoppa et al. 2012; Lierenfeld and Mattsson 2015). Abundant ultramafic xenoliths and clinopyroxene, amphibole and/or phlogopite megacrysts/macrocrysts appear scattered within the Cerro Pelado and El Aprisco pyroclastic deposits. Mafic megacrysts have not been previously studied in detail in these volcanic centres. The variety and size of these mafic megacrysts are higher in the Cerro Pelado pyroclastic fall deposits than in other CVF centres. Moreover, mantle xenoliths are also present in these volcanoes and they have been recently described and interpreted as peridotites that have undergone small-to-moderate degrees of partial melting $(\leq 10 \%)$, and some of them variably overprinted by different metasomatic agents, mostly alkaline silica-undersaturated melts (Villaseca et al. 2010; Lierenfeld and Mattsson 2015; Andía et al. 2018), but also carbonatite fluids or melts (e.g., González-Jiménez et al. 2014; Villaseca et al. 2019).

Preliminary studies on these megacrysts have shown that they are related to magmatic chambers at mantle depths (Dorado et al. 2016), a similar interpretation to the high$\mathrm{P}$ antecryst origin of clinopyroxene megacrysts from the 
Fig. 1 a Calatrava volcanic field and location of the volcanic centres mentioned in this study (Ancochea 1982; Cebriá et al. 2011). b Sketch map of the Iberian Peninsula showing the location of the Cenozoic volcanic fields in Spain (Lustrino and Wilson 2007), (1) Calatrava or central region, (2) SE region, (3) Levante region and (4) Olot or NE region

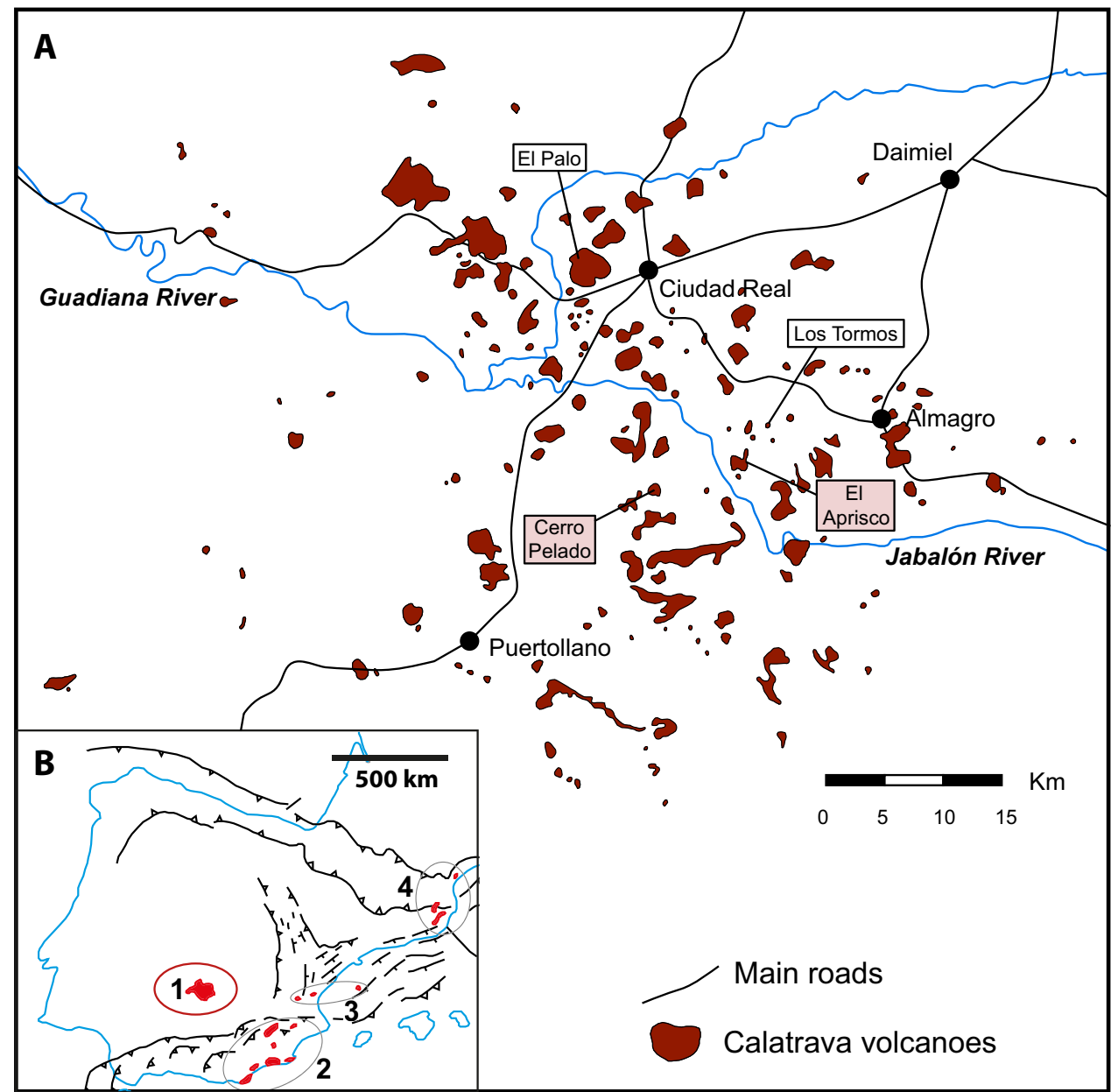

Los Tormos (CVF, Andía et al. 2018) or the Sant Corneli (Olot field, Galán et al. 2017) volcanoes. Nevertheless, other authors consider that some of these megacrysts and the accompanying phenocrysts might be generated by mechanical disintegration of the mantle peridotite cargo (Lierenfeld and Mattsson 2015). Studies on the associated amphiboleand phlogopite-bearing clinopyroxenite enclaves from these CVF volcanoes have never been undertaken. In this work, we add new chemical data on the composition of the Cerro Pelado and El Aprisco megacrysts, on minerals of clinopyroxenite and glimmerite (phlogopite-rich clinopyroxenite) enclaves, together with phenocrysts from the host alkaline magmas.

The purpose of this study is twofold. First, to describe the petrography and chemical composition of the mafic megacrysts and clinopyroxenite enclaves, discussing their petrogenetic relationships. Second, to constrain the degree of consanguinity between megacrysts, enclaves and their host lavas, thus determining whether they represent fragments of the mantle wall-rocks (peridotite s.l.) or deep-seated cumulates (clinopyroxenite s.l.). This work, along with previous geochemical data of the CVF mantle xenoliths, could contribute to a better characterization of the mantle beneath Central Iberia and also to the understanding of the complex magmatic plumbing system beneath monogenic volcanic fields.

\section{Geological setting}

The CVF is exclusively formed by monogenetic volcanic centres situated at the western termination of the SSW-NNE tectonic basin of the Guadiana river valley (Fig. 1). It represents a typical intracontinental alkaline magmatic event within the Neogene-Quaternary western and central European province, located in the limit with the Variscan terranes (Cebriá and López Ruiz 1995; Villaseca et al. 2010). The CVF host rocks are mainly Palaeozoic quartzites and slates deformed by the Variscan orogeny and forming E-W and $\mathrm{N}-\mathrm{S}$ vertical, flexural folds. Later, the Alpine orogeny drove a generalised uplift of this zone with an important fragile deformation (López Ruiz et al. 2002; De Vicente and Vegas 2009). 
The volcanic activity of the CVF started in the Late Miocene and can be separated in two periods by $\mathrm{K}-\mathrm{Ar}$ age dating. The first period (8.7-6.4 Ma) was dominated by leucititic magmas forming only one volcanic centre (Morrón de Villamayor). The second period (3.7-0.7 Ma) was dominated by basaltic (melilitites, nephelinites, basanites) magmas (Cebriá and López Ruiz 1995; Ancochea 2004; Herrero-Hernández et al. 2015; Villaseca et al. 2019). Thus, the CVF volcanic rocks can be mainly classified in four different groups: olivine melilitites, olivine nephelinites, alkaline olivine basalts and olivine leucitites.

The geodynamic setting of this volcanism is still controversial, with the debate focused on four main models: (1) volcanic clustering related to asthenospheric mantle upwelling in a pre-rifting stage (Ancochea 1982; López Ruiz et al. 1993); (2) a megafault system affecting the western Mediterranean European block (López Ruiz et al. 2002); (3) the reactivation of previous NW-SE fractures during the extensional regime induced by the accretion of the Betic ranges (Cebriá et al. 2011); and (4) mantle instabilities in a back-arc position during the roll-back of the Alboran slab (Carminati et al. 2012; Granja Bruña et al. 2015).

The trace element composition and the isotopic data of primary alkaline and ultralkaline ultrabasic magmas suggest that most of the Calatrava suites are derived from an enriched (but relatively homogeneous) asthenospheric reservoir, similar to that defined for the European asthenospheric mantle (Ancochea 1982; Cebriá and López Ruiz 1995; Granet et al. 1995). Some of the CVF magmas carried a complex suite of ultramafic xenoliths, as well as a group of different megacrysts, which origin is the main topic of this work.

Clinopyroxene, amphibole and phlogopite megacrysts are found in different CVF volcanoes, but the presence of cm-size of two hydrous mafic megacrysts (amphibole, phlogopite) is commonly recorded in the pyroclastic fall deposits from the Cerro Pelado scoria cone, formed by olivine nephelinites (Fig. 2a). The olivine melilitites of the El Aprisco maar only show fragments of different size of clinopyroxene and amphibole megacrysts. Ultramafic clinopyroxene-rich enclaves with variable amounts of hydrous minerals (amphibole and phlogopite), and olivine in rare cases, can be found commonly associated to these megacrysts in both volcanoes. A scarce variety of phlogopite-rich clinopyroxenites (glymmerites, mica > 90 vol\%) appears in the El Aprisco maar.

\section{Analytical methods}

A total number of 22 samples have been selected for the present study: 12 from the Cerro Pelado scoria cone and 10 from the El Aprisco maar. Major element composition of minerals was performed on polished thin sections (carbon coated) of representative samples of megacrysts and ultramafic enclaves with a JEOL Superprobe JXA 8900-M (Centro Nacional de Microscopía Electrónica "Luis Bru", Universidad Complutense de Madrid), equipped with four wavelength-dispersive mode spectrometers. The acceleration voltage was $15 \mathrm{kV}$ and the beam current $20 \mathrm{nA}$, with variable counting times: $10 \mathrm{~s}$ on the peak and $5 \mathrm{~s}$ on each background position. The beam diameter ranged from 2 to $5 \mu \mathrm{m}$ to minimize grain damage. Absolute abundance for each element was determined by comparison with sillimanite, albite, almandine, kaersutite, microcline, ilmenite, F-apatite, scapolite, Ni alloy, chromite, gahnite, bentonite and strontianite. Detection limits are $0.02 \mathrm{wt} \%$ for $\mathrm{Al}, \mathrm{Na}$, $\mathrm{K}$ and $\mathrm{P}, 0.03 \mathrm{wt} \%$ for $\mathrm{Ti}, \mathrm{Fe}, \mathrm{Mn}, \mathrm{Mg}, \mathrm{Ni}$ and $\mathrm{Cr}$ and 0.04 $\mathrm{wt} \%$ for $\mathrm{Si}$. Error limits for each element depend strongly on the absolute concentration in each phase, but could be estimated significantly for the $<1 \mathrm{wt} \%$ level (with error $>10 \%$ ). Concentrations below $0.2 \mathrm{wt} \%$ are quoted, but considered qualitative. An on-line ZAF program was used for data correction. Mineral analyses were assisted by appropriate backscattered electron (BSE) images to ensure that representative and homogeneous points were selected for analysis.

\section{Petrography}

\subsection{Host rocks}

The studied olivine nephelinites and melilitites show a porphyritic texture, with the main phenocrysts being clinopyroxene and olivine, within a hypocrystalline groundmass composed of dark to brown vesiculated glass, clinopyroxene, olivine, nepheline (Cerro Pelado), melilite (El Aprisco) and accessory Ti-magnetite. Clinopyroxene phenocrysts, the most abundant mineral, are up to $9 \mathrm{~mm}$ in size, usually euhedral zoned crystals. The Cerro Pelado volcano shows two types of relict clinopyroxene cores: (1) anhedral green, and (2) anhedral to euhedral colourless, whereas in the El Aprisco maar only the second type of relic clinopyroxene core has been observed (although green clinopyroxene phenocryst cores have been described by Lierenfeld and Mattsson 2015). Both cores develop pale purple rims. Olivine phenocrysts are less abundant than clinopyroxene and display lower size (up to $4.5 \mathrm{~mm}$ ), highly variable within a single sample. The larger olivines usually present anhedral cores and thin rims indicative of chemical zoning, whereas small microphenocrysts display continuous normal zoning and euhedral shape. The volcanic host rocks also include xenocrysts from the fragmentation of mantle xenoliths (e.g., Fo-rich olivine, orthopyroxene and $\mathrm{Al}-\mathrm{Mg}$-rich spinel), together with megacrysts (amphibole, phlogopite, clinopyroxene) and clinopyroxenite and glimmerite enclaves. 


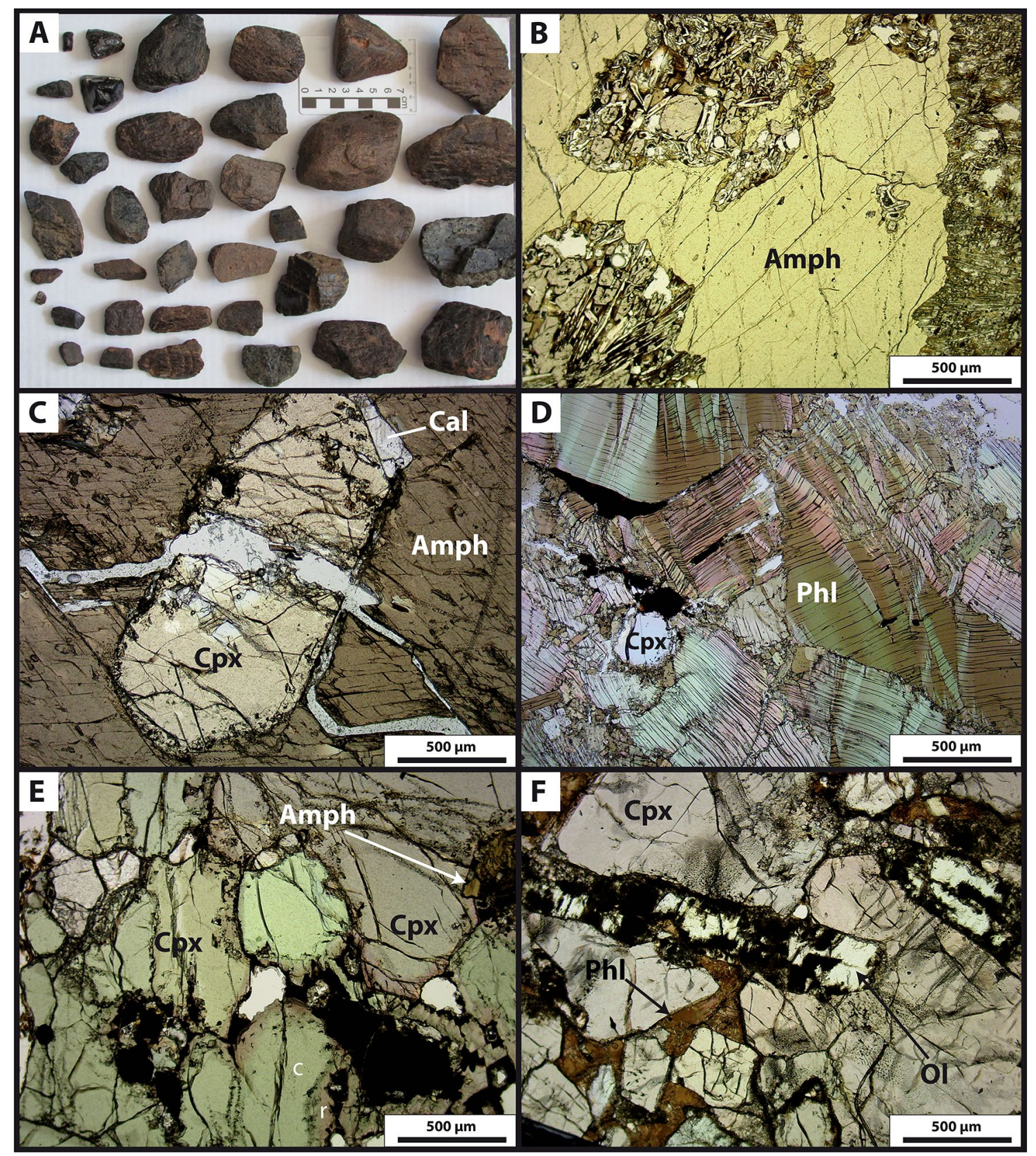

Fig. 2 Petrographic characteristics of El Aprisco and Cerro Pelado representative samples. a Megacrysts sampled in the Cerro Pelado volcano (mostly amphibole) up to $8 \mathrm{~cm}$ in length. b Amphibole megacryst showing melt blobs of host volcanic melt composed of skeletal olivine, prismatic clinopyroxene and vesicular brown glass (115599, El Aprisco). c Amphibole megacryst showing a clinopyroxene inclusion and interstitial calcite (114404, El Aprisco). Open fractures

\subsection{Megacrysts}

The size difference between phenocryst and megacryst is artificially established at very coarse-grain values (i.e., $5 \mathrm{~mm}$ ), and the term macrocrysts is normally used for intermediate values (5-0.5 mm) (e.g., Bussweiler et al. 2015). made after thin section preparation. d Glimmerite (phlogopite-rich) enclave (65287, Cerro Pelado) with kink banding in mica crystals. e Clinopyroxenite enclave showing zoned clinopyroxene with green core (c) and brownish rim (r) (115591, El Aprisco). f Clinopyroxenite enclave showing elongated olivine crystals within clinopyroxene and phlogopite (115592, El Aprisco). Mineral abbreviations after Kretz (1983)

Hydrous mafic minerals never appear within the volcanic rock groundmass, but clinopyroxene shows a wide size range between megacryst and phenocryst. Clinopyroxene, amphibole and phlogopite megacrysts can be found as single pyroclasts (lapillus) or as small fragments in the Cerro Pelado and El Aprisco pyroclastic rocks. Clinopyroxene megacrysts 


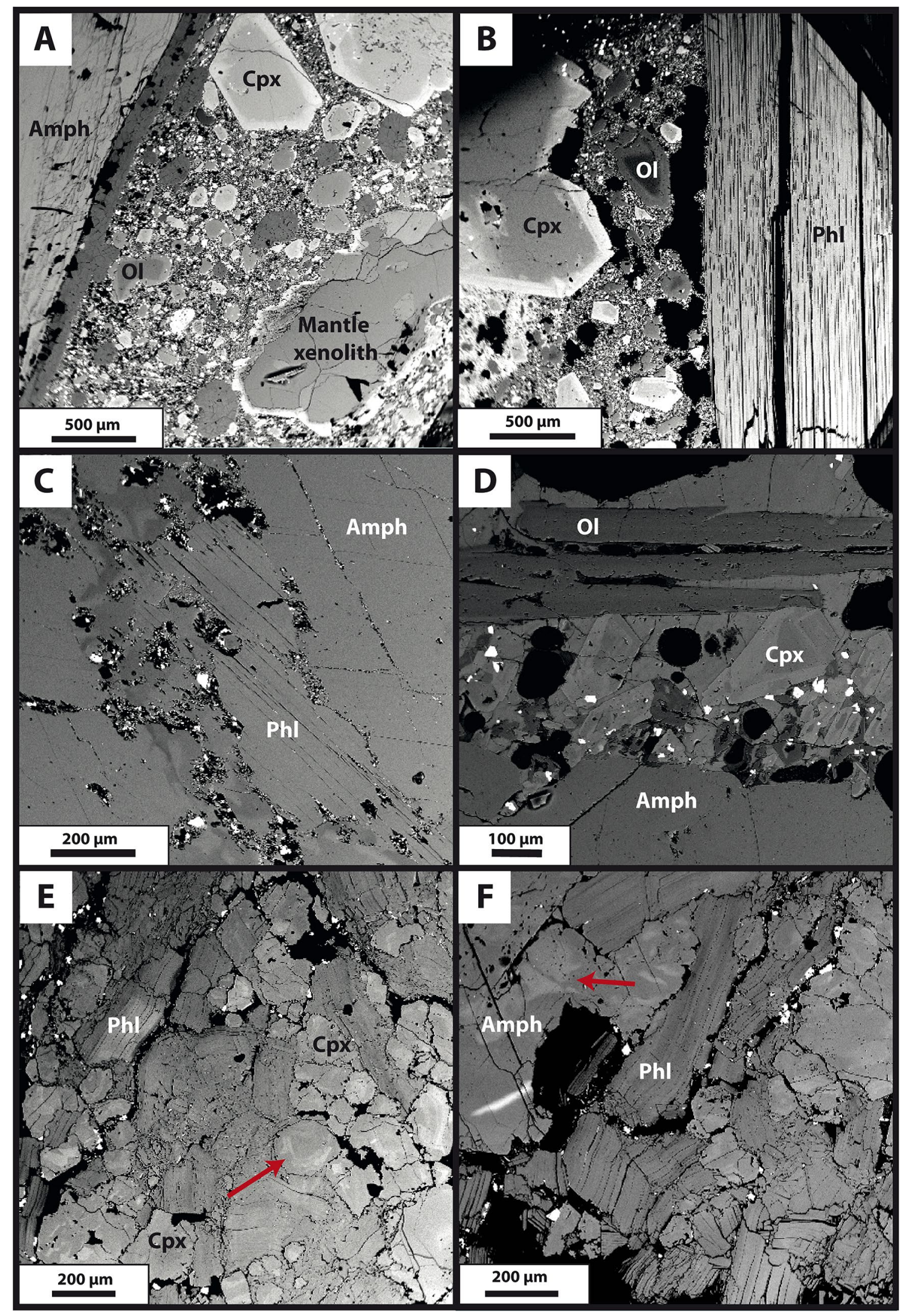


4Fig. 3 Back scattered electron images of representative minerals from El Aprisco and Cerro Pelado samples. a Amphibole (amph) megacryst with a zeolitized rim formed by interaction with the host melilitite melt (115603, El Aprisco). Peridotite xenolith and zoned olivine (ol) and clinopyroxene (cpx) phenocrysts sorrounded by the olivine melilitite groundmass (right hand side of the picture). b Phlogopite megacryst and olivine nephelinite showing zoned clinopyroxene and olivine phenocrysts from Cerro Pelado (114403). c Phlogopite microinclusion within amphibole megacryst (110852, Cerro Pelado). d Melt embayment within an amphibole megacryst (115599, El Aprisco). Skeletal olivine and zoned prismatic clinopyroxene crystals within vesicular glass. e Amphibole- and phlogopite-rich clinopyroxenite enclave (115601, El Aprisco). Arrow marks a patchy zoned clinopyroxene crystal. f Sector or patchy zoning area of an amphibole crystal from the same 115601 enclave (see arrow). Mineral abbreviations after Kretz (1983)

are colourless and mostly unzoned, except for a thin reaction rim with the host magma, and their size reaches up to $6.5 \mathrm{~cm}$. Amphibole is the largest megacryst (up to $8.5 \mathrm{~cm}$ in the Cerro Pelado volcano) and displays brown colour, and euhedral to anhedral shape (Fig. 2a) and occasionally patchy zoning. Phlogopite is anhedral, usually rounded, unzoned and no larger than $4.5 \mathrm{~cm}$. Most megacrysts display reaction rims (Fig. 3a, b) or corrosion gulfs. For instance, some amphibole megacrysts have a thin dark glassy rim, likely resulting from the interaction with the host alkaline magma. Equivalent reaction textures are also manifested by the presence of infiltrating veinlets or embayments of basaltic melt permeating some megacrysts (Fig. 2b), giving rise to irregular blobs showing skeletal olivine, clinopyroxene microcrystals and vesicle-bearing interstitial brown glass (Figs. 2b, 3d). Megacrysts can also enclose fluid/glass inclusions, small clinopyroxene, amphibole and phlogopite crystals (similar in composition to megacrysts) and accessory opaque minerals, such as Fe-rich pyrrothite, which appears as large (up to $1.5 \mathrm{~mm}$ ) anhedral to euhedral crystals or elongated rods, and Ti-magnetite microinclusions.

\subsection{Ultramafic enclaves}

Apart from typical mantle xenoliths of peridotitic composition described in previous works (Villaseca et al. 2010; González-Jiménez et al. 2014; Lierenfeld and Mattsson 2015; Villaseca et al. 2019), the studied pyroclastic rocks also include small black elongated enclaves. These enclaves can be classified as hornblende clinopyroxenite, hornblendephlogopite clinopyroxenite, phlogopite clinopyroxenite and glimmerite ( $>90 \%$ phlogopite) (Fig. 2d), in order of abundance. Their size ranges from 1 to $7 \mathrm{~cm}$. They show mostly medium- to fined-grained equigranular texture (Fig. 2e). Granoblastic fabric is absent, while the presence of euhedral olivine and clinopyroxene, interstitial phases (amphibole and phlogopite) and poikilitic crystals (amphibole and phlogopite) are features indicative of igneous texture. However, occasional deformation textures can be observed such as kink bands in phlogopite from glimmerites (Fig. 2d), likely associated with crystal compaction or repeated collisions with the conduit walls during ascent (e.g., Peterson and LeCheminant 1993). Olivine does not show zoning and has been found only in one clinopyroxenite enclave (Fig. 2f). Clinopyroxene can be colourless or pale green and displays complex sector or oscillatory zoning ending in a discordant thin purple rim (Figs. 2e, 3e), resembling the two types of phenocryst cores described in the olivine nephelinite from Cerro Pelado. Amphibole may also show slight zoning in the form of irregular patches (Fig. 3f). The main accessory phases are Ti-magnetite, which is usually intergranular, and titanite and ilmenite, which have been found in irregular reactional zones together with clinopyroxene and skeletal olivine microcrystals.

\section{Mineral chemistry}

\subsection{Olivine}

Analysed olivines display a heterogeneous composition with characteristic high forsterite contents $\left(\mathrm{Fo}_{78-91}\right)$ (Table 1). Olivines with the most primitive composition are phenocryst cores $(\mathrm{Mg} \#=0.87-0.91$ and $\mathrm{NiO}=0.2-0.48 \mathrm{wt} \%)[\mathrm{Mg} \#$ is $\mathrm{MgO} /(\mathrm{MgO}+\mathrm{FeO})$ on a molecular basis], whereas rims display $\mathrm{TiO}_{2}$ and $\mathrm{CaO}$ up to $0.13 \mathrm{wt} \%$ and $1 \mathrm{wt} \%$, respectively (Fig. 4). Some phenocryst cores have similar major element composition to olivine from peridotite xenoliths (Fig. 4), as also described by Lierenfeld and Mattsson (2015) in El Aprisco melilitites. A minor xenocrystic contribution to the olivine crystal cargo is not discarded for some corroded $\mathrm{Ca}$ poor and $\mathrm{Mg}-\mathrm{Ni}$-rich cores of large phenocrysts (see also Lierenfeld and Mattsson 2015).

The elongated crystals found in clinopyroxenite enclaves (Fig. 2f) show slightly lower Mg\# and $\mathrm{NiO}$ concentrations than the phenocryst cores, but broadly plot within the general chemical evolution defined by the core-to-rim trend: $\mathrm{NiO}$ and $\mathrm{SiO}_{2}$ decrease and $\mathrm{CaO}$ and $\mathrm{TiO}_{2}$ increase towards lower Mg\# (Fig. 4). This elongated olivine shows a wide range of $\mathrm{TiO}_{2}$ contents (Fig. 4a), being the Ti-richest crystals those adjacent to interstitial phlogopite. It is noteworthy the higher $\mathrm{CaO}$ contents of phenocryst rims with respect to olivine in clinopyroxenite enclaves with equivalent $\mathrm{Mg \#}$ (Fig. 4c). Skeletal olivine found in melt embayments (blobs) within megacrysts has similar composition to those of phenocryst rims (Table 1).

\subsection{Clinopyroxene}

Clinopyroxene can be classified mainly as diopside and shows the most complex composition in our database, 
Table 1 Major element composition of representative olivine from El Aprisco and Cerro Pelado samples

\begin{tabular}{|c|c|c|c|c|c|c|c|}
\hline Sample & 115605 & 115605 & 114403 & 114403 & 115599 & 115591 & 115592 \\
\hline Analysis & 80 core & $82 \mathrm{rim}$ & 12 core & $13 \mathrm{rim}$ & 26 & 27 & 39 \\
\hline \multirow[b]{2}{*}{ Volcano } & \multicolumn{4}{|l|}{ Phenocryst } & \multicolumn{2}{|l|}{ Skeletal } & Clpxenite $^{\mathrm{a}}$ \\
\hline & El Aprisco & El Aprisco & C. Pelado & C. Pelado & El Aprisco & El Aprisco & El Aprisco \\
\hline $\mathrm{SiO}_{2}$ & 40.20 & 40.37 & 39.97 & 40.87 & 39.13 & 39.00 & 40.15 \\
\hline $\mathrm{TiO}_{2}$ & 0.05 & 0.04 & 0.01 & 0.05 & 0.10 & 0.06 & 0.04 \\
\hline $\mathrm{Al}_{2} \mathrm{O}_{3}$ & 0.00 & 0.04 & 0.08 & 0.09 & 0.06 & 0.05 & 0.07 \\
\hline $\mathrm{Cr}_{2} \mathrm{O}_{3}$ & 0.03 & 0.02 & nd & nd & 0.02 & 0.05 & 0.08 \\
\hline $\mathrm{FeO}$ & 8.83 & 12.52 & 8.89 & 12.94 & 16.90 & 18.42 & 14.28 \\
\hline $\mathrm{MnO}$ & 0.14 & 0.20 & 0.19 & 0.14 & 0.07 & 0.24 & 0.06 \\
\hline $\mathrm{MgO}$ & 48.95 & 45.14 & 47.97 & 46.48 & 43.61 & 41.16 & 45.54 \\
\hline $\mathrm{CaO}$ & 0.06 & 0.64 & 0.09 & 0.35 & 0.82 & 0.89 & 0.24 \\
\hline $\mathrm{Na}_{2} \mathrm{O}$ & 0.00 & 0.00 & 0.02 & 0.03 & 0.01 & 0.00 & 0.01 \\
\hline $\mathrm{K}_{2} \mathrm{O}$ & 0.00 & 0.00 & 0.00 & 0.01 & 0.02 & 0.00 & 0.00 \\
\hline $\mathrm{NiO}$ & 0.48 & 0.13 & 0.31 & 0.06 & 0.00 & 0.03 & 0.21 \\
\hline Total & 98.74 & 99.10 & 97.53 & 101.01 & 100.74 & 99.91 & 100.69 \\
\hline $\mathrm{XMg}$ & 0.91 & 0.87 & 0.91 & 0.86 & 0.82 & 0.80 & 0.85 \\
\hline
\end{tabular}

$n d$ not determined

${ }^{\mathrm{a}}$ Clinopyroxenite enclave as it appears in ultramafic enclaves, as megacryst, phenocryst and small inclusions within other minerals (e.g., amphibole) (Table 2). This variability is reflected in wide compositional ranges (i.e. $\mathrm{Mg} \#, \mathrm{TiO}_{2}, \mathrm{Al}_{2} \mathrm{O}_{3}, \mathrm{Cr}_{2} \mathrm{O}_{3}$; Fig. 5), and in complex zoning patterns (Figs. 6, 7). Clinopyroxene megacrysts show Mg\# values indicative of a primitive composition, with only a minor variation between volcanoes (0.81-0.83 in El Aprisco and 0.83-0.84 in Cerro Pelado) (Table 2). Most elements define fairly restricted ranges (i.e., $\mathrm{TiO}_{2}=1-2 \mathrm{wt} \%, \mathrm{Na}_{2} \mathrm{O}=1-1.4 \mathrm{wt} \%$, $\mathrm{Al}_{2} \mathrm{O}_{3}=6-9 \mathrm{wt} \%$ ). When reaction rims appear around megacrysts, they show a low Mg composition, overlapping that of the phenocryst rims.

Clinopyroxene in clinopyroxenite and glimmerite enclaves overlaps the field of megacrysts, but also plots towards a more differentiated composition (Fig. 5). The zoning profiles are indicative of a complex chemical evolution, broadly characterized by the alternation of $\mathrm{Si}-\mathrm{Mg}$ and Fe-Al-Ti-Na-rich bands (Fig. 6a, b). When significant chemical differences exist within a single crystal, the $\mathrm{Mg}$ and Fe-rich zones are colourless and pale green, respectively. The exception to this zoning is that found in enclave 115591, which presents homogeneous pale green clinopyroxene with a thin Mg-Ti-rich and Na-poor rim (Fig. 6c), similar to the groundmass crystals. The core to rim enrichment in $\mathrm{Al}, \mathrm{Ti}$ and Na concentrations shown by the zoned minerals represents a first stage in the chemical evolution of these clinopyroxenes. A second stage is visible if the whole compositional spectrum of these enclaves is considered, characterized by a decrease in $\mathrm{Ti}$ and $\mathrm{Na}(\mathrm{Al})$ contents (Fig. 5a, b, d).
We have found two types of clinopyroxene phenocryst cores in the Cerro Pelado volcanic rocks: colourless and green. They show a contrasting composition, with the green cores exhibiting lower $\mathrm{Mg} \#, \mathrm{TiO}_{2}$ and $\mathrm{Al}_{2} \mathrm{O}_{3}$, and higher $\mathrm{Na}_{2} \mathrm{O}$ contents than colourless clinopyroxene (Fig. 5). This chemical distinction between green and colourless phenocrysts has also been observed in the El Aprisco melilitites (Lierenfeld and Mattsson 2015). Both phenocryst cores are mostly homogeneous but develop a strong chemical zoning (Fig. 7), manifested in the formation of purple rims. These rims are similar in composition, irrespective of the type of core considered, and are characterized by higher $\mathrm{TiO}_{2}$, $\mathrm{Al}_{2} \mathrm{O}_{3}$ and lower $\mathrm{Na}_{2} \mathrm{O}$ contents (Fig. 5a, b, d) with respect to the corresponding cores. These features are also evident in the zoning profiles, where it is appreciable that colourless cores are subhedral to euhedral and display normal zoning (Fig. 7a), whereas green cores are variably corroded, anhedral and show reverse zoning (Fig. 7b). In general terms, the core to rim chemical variation is fairly high, as clearly illustrated by the $\mathrm{TiO}_{2}$ and $\mathrm{Al}_{2} \mathrm{O}_{3}$ ranges $(\sim 1-7 \mathrm{wt} \%$ and 5-11 wt \%, respectively) (Fig. 5a, b). It is also remarkable the similitude in composition of the colourless phenocryst cores, megacrysts and most clinopyroxenes from the pyroxenite enclaves.

The clinopyroxene composition of lherzolite and wehrlite xenoliths found in these volcanoes has been plotted in Fig. 5 for comparison. Lherzolite clinopyroxene displays higher $\mathrm{Mg \#} \mathrm{(0.86-0.93)} \mathrm{and} \mathrm{Cr}_{2} \mathrm{O}_{3}(0.35-1.5 \mathrm{wt} \%$ ) (Fig. 5c), and lower $\mathrm{TiO}_{2}(<1 \mathrm{wt} \%)$, with respect to other types of clinopyroxene (Villaseca et al. 2010). Moreover, they do not follow 

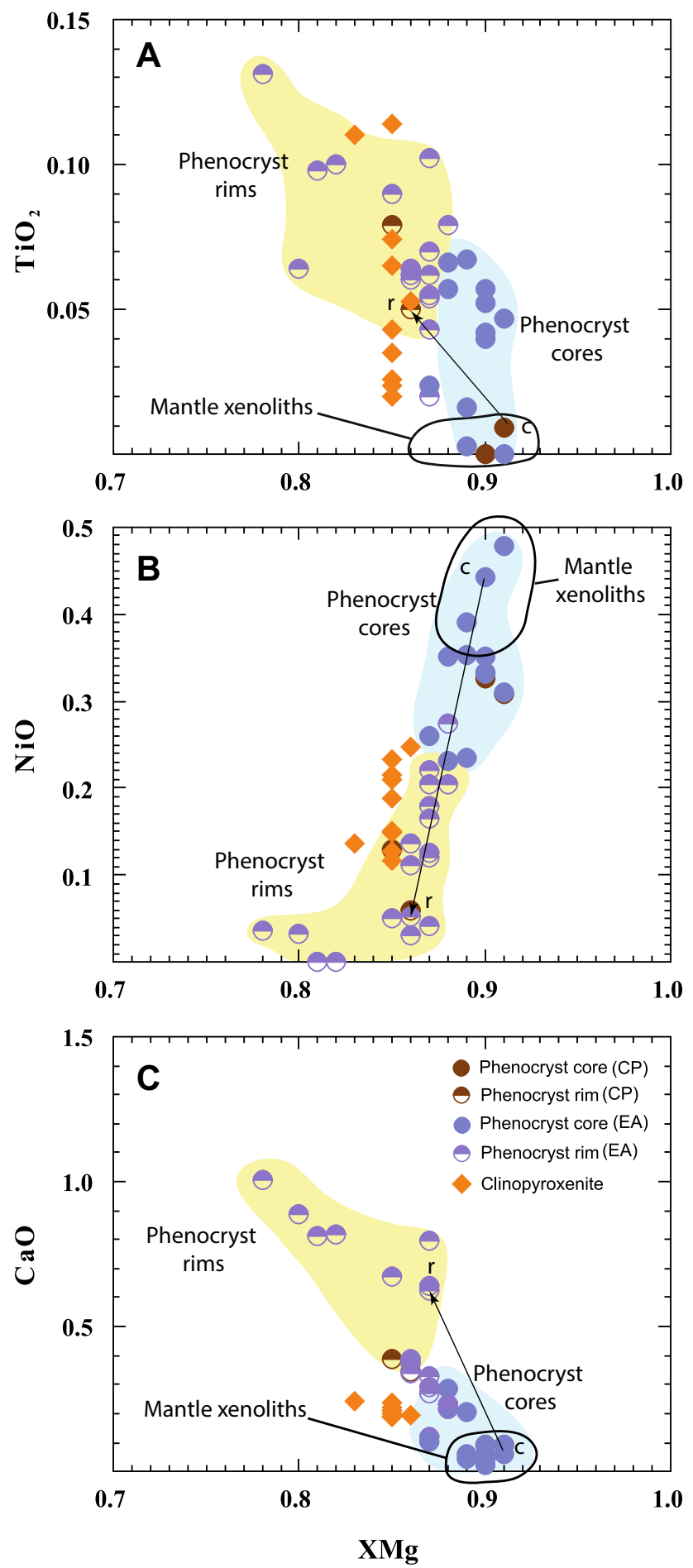

Fig. 4 Representative diagrams of major element composition of olivines from the El Aprisco and Cerro Pelado volcanoes. XMg is the Mg-number. Peridotite xenolith analyses are taken from Andía (2017). Arrow marks core-to-rim zoning in a single crystal. Olivine compositional field from peridotite mantle xenoliths is taken from Villaseca et al. (2010) and González-Jiménez et al. (2014) data

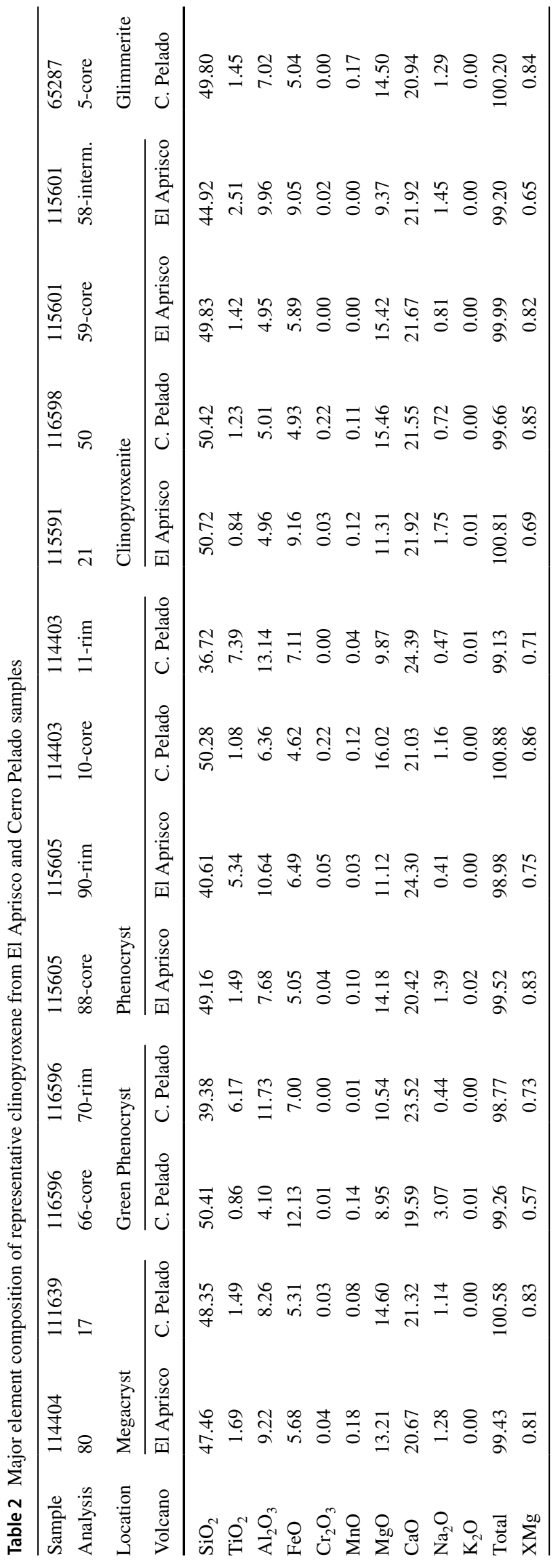



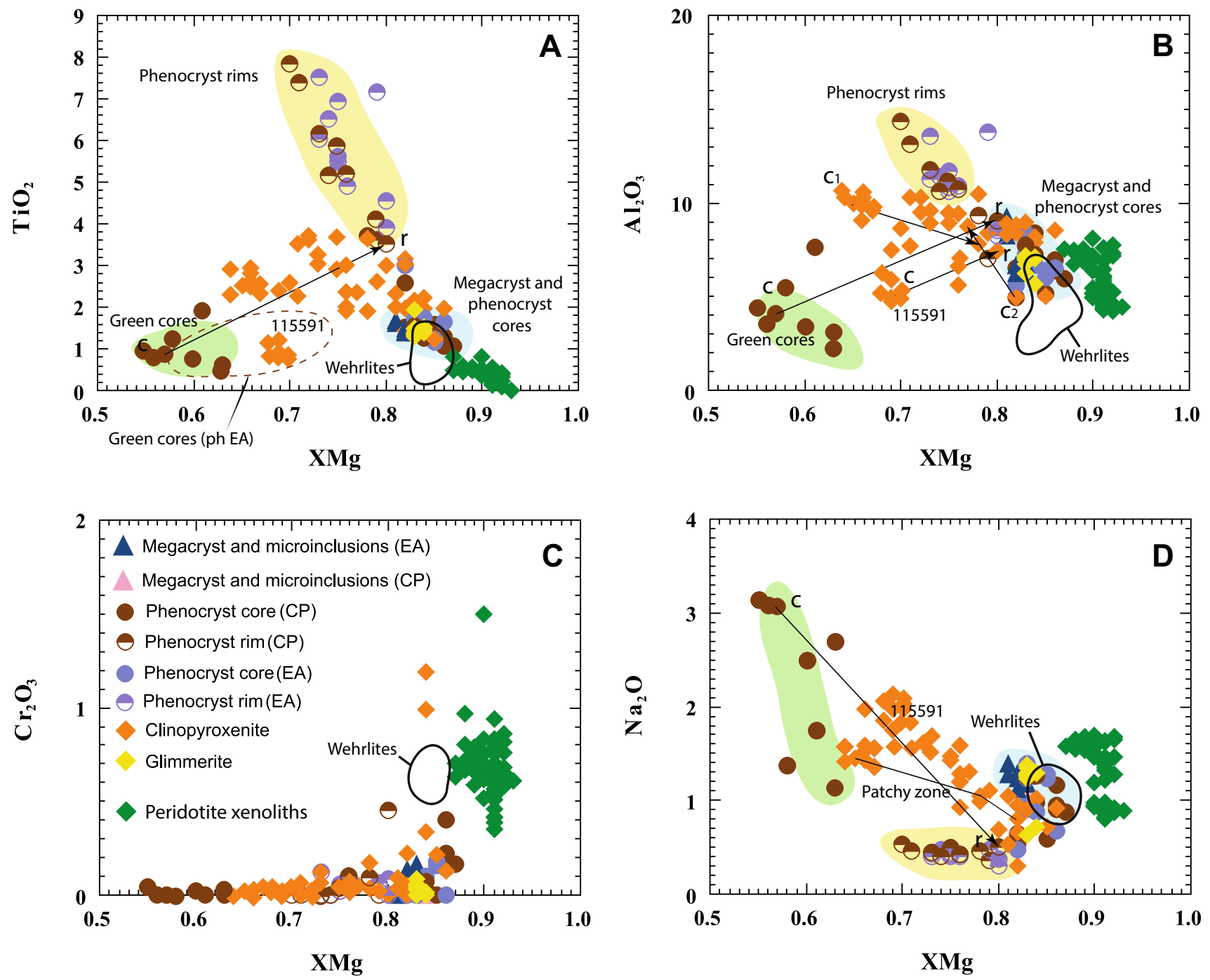

Fig. 5 Representative diagrams of major element composition of clinopyroxenes from the El Aprisco and Cerro Pelado volcanoes. $\mathrm{XMg}$ is the Mg-number. The green $\left(\mathrm{c}_{1}\right)$ and colourless $\left(\mathrm{c}_{2}\right)$ clinopyroxene crystals from pyroxenite 115601 (El Aprisco) show two distinct zoning patterns (see arrows). Green phenocryst-core com-

the same differentiation trend, as illustrated by $\mathrm{Al}_{2} \mathrm{O}_{3}$ and $\mathrm{Na}_{2} \mathrm{O}$ contents (Fig. 5b, d). These discrepancies preclude a genetic relationship between megacrysts or phenocryst cores and the lherzolitic mantle. Clinopyroxene from wherlite xenoliths presents a chemical composition more akin to that of the most primitive cpx of clinopyroxenite enclaves, megacrysts and phenocryst cores, except for their higher $\mathrm{Cr}_{2} \mathrm{O}_{3}$ values (Fig. 5c).

\subsection{Amphibole}

The amphibole megacrysts found in the Cerro Pelado and El Aprisco volcanoes can be classified mostly as pargasites, though Mg-hastingsites and kaersutites are also present positional field from El Aprisco melilitites (ph EA) are taken from Lierenfeld and Mattsson (2015). Clinopyroxene from peridotite and wehrlite xenoliths are taken from Villaseca et al. (2010) and González-Jiménez et al. (2014)

(Leake et al. 2004). There is a significant resemblance in the composition of megacrysts from both volcanoes, so that they constitute a coherent group displaying a moderate chemical variation (Fig. 8). Only a slight enrichment in $\mathrm{Al}_{2} \mathrm{O}_{3}, \mathrm{CaO}$, $\mathrm{TiO}_{2}$ and $\mathrm{K}_{2} \mathrm{O}$ is appreciated in Cerro Pelado with respect to megacrysts from El Aprisco. $\mathrm{Mg} \#$ may reach high values (up to 0.83 ; Fig. 8 ) (Table 3 ), indicative of a fairly primitive composition, and is positively correlated with $\mathrm{Al}_{2} \mathrm{O}_{3}$ (12.4-15.9 wt\%) and $\mathrm{K}_{2} \mathrm{O}$ (1.6-2.4 wt\%) (Fig. 8b, d). $\mathrm{CaO}$ is quite homogeneous and $\mathrm{TiO}_{2}$ exhibits a more ambiguous behavior, although the lower $\mathrm{Mg \#}$ values in sample 115599 with respect to the rest of megacrysts from El Aprisco, point to a subtle Ti decrease towards the evolved terms (Fig. 8). Patchy zoning and smaller amphibole crystals can 

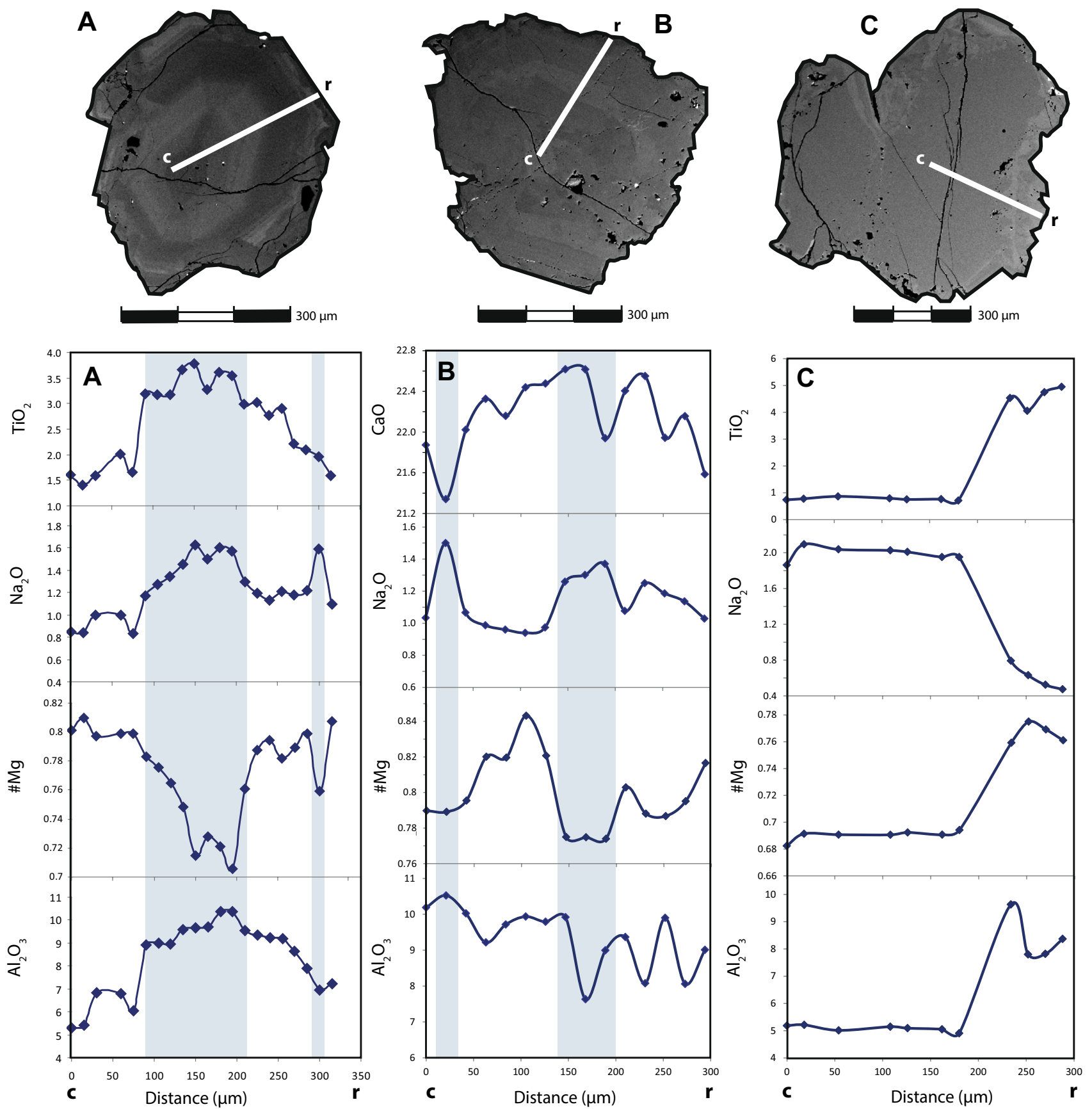

Fig. 6 Zoning profiles showing compositional variations within three clinopyroxene crystals in clinopyroxenite enclaves: a sample 115601 from El Aprisco, b sample 116598 from Cerro Pelado, and c sample

be observed occasionally, characterized by a slightly higher $\mathrm{TiO}_{2}$ and $\mathrm{Al}_{2} \mathrm{O}_{3}$ contents (Table 3, analysis 111656-39).

Amphibole from pyroxenite enclaves yields a more heterogeneous composition than megacrysts (Table 3), although certain overlapping between both fields exists (Fig. 8). Mg\# is lower (0.59-0.72) in some pyroxenites drawing a tendency of decreasing $\mathrm{Ti}, \mathrm{Al}$ and $\mathrm{Ca}$ towards the most evolved composition (Fig. 8). Amphiboles in
115591 from El Aprisco. Back-scattered electron images showing the internal texture and profile position are shown at the top of each column. $c$ core, $r$ rim

these ultramafic enclaves show a patchy zoning similar to that of some megacrysts. In this respect, the analyses of enclave 115601, which show a slight increase in $\mathrm{K}_{2} \mathrm{O}$ con-

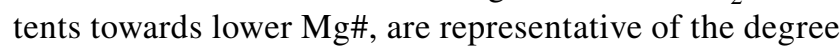
of evolution depicted by amphibole zoning. Amphibole is absent in glimmerite enclaves from the Cerro Pelado volcano, but it has been found in the phlogopite-bearing clinopyroxenite 115601 from El Aprisco. 


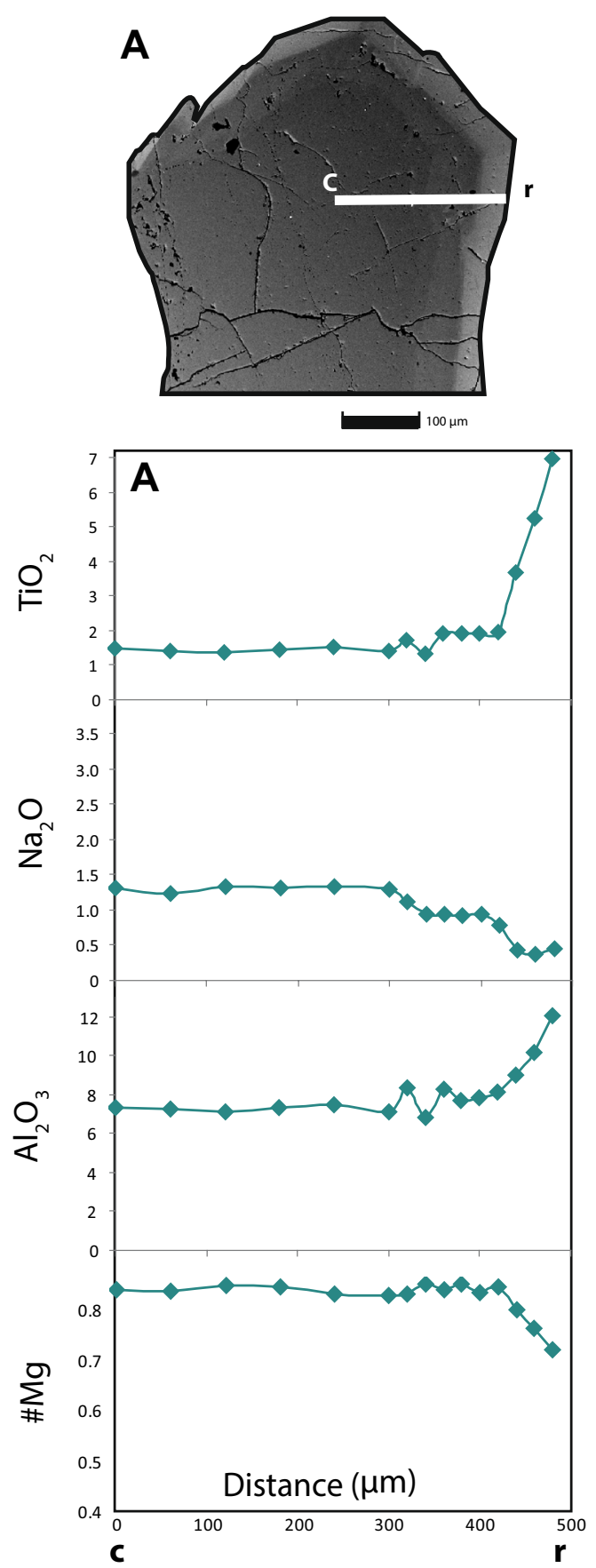

Fig. 7 Zoning profiles showing compositional variations within clinopyroxene phenocrysts from the Cerro Pelado nephelinite: a colourless core and $\mathbf{b}$ green cores in sample 116596. Chemical profile in plot B (ph.2) has been extrapolated considering the BSE domains in

The composition of amphibole from peridotite xenoliths found in the same volcanoes has also been plotted in Fig. 8 for comparison. These amphiboles, interstitial and of very small size, have been interpreted as due to mantle

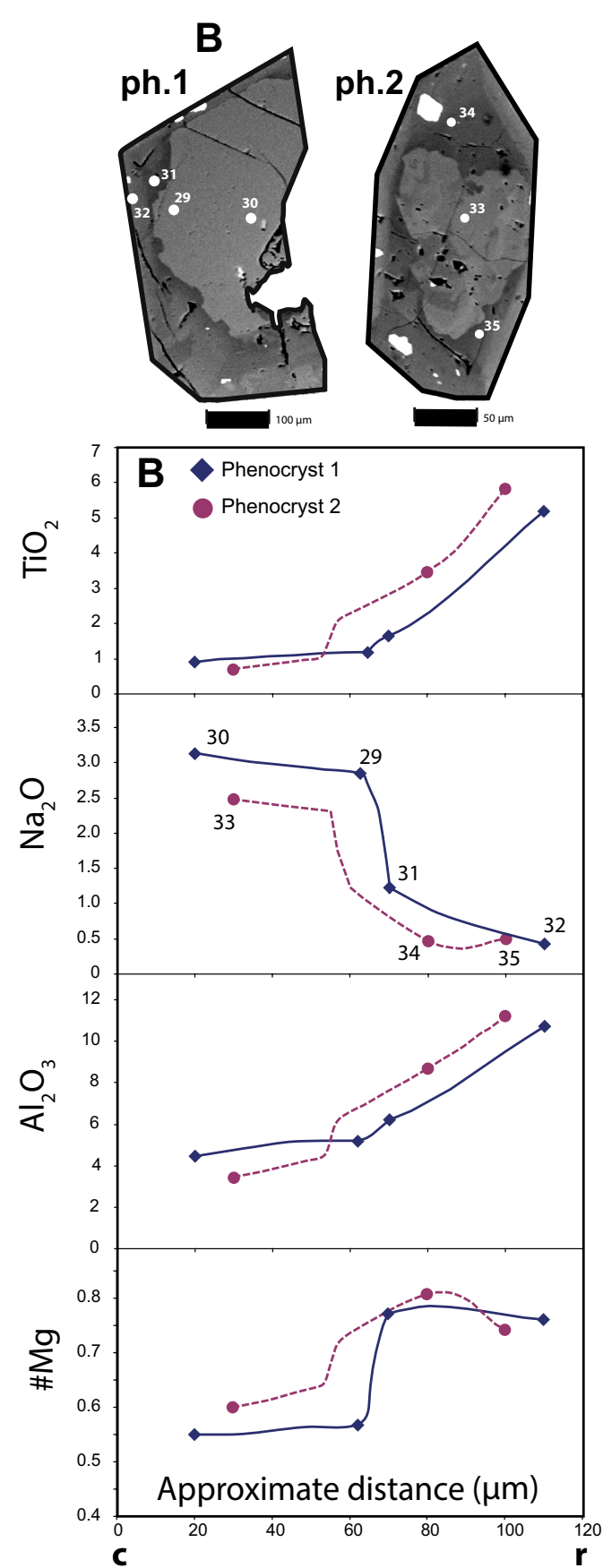

the crystal due to the scarcity of data. Back-scattered electron (BSE) images showing the internal texture and profile position are shown at the top of each column. $c$ core, $r$ rim

metasomatism (Villaseca et al. 2010, 2019). They exhibit much higher $\mathrm{Mg \#}, \mathrm{Cr}_{2} \mathrm{O}_{3}$ and $\mathrm{Na}_{2} \mathrm{O}$, and fairly lower $\mathrm{K}_{2} \mathrm{O}$ and $\mathrm{TiO}_{2}$ than megacrysts and amphiboles from pyroxenitic enclaves. 

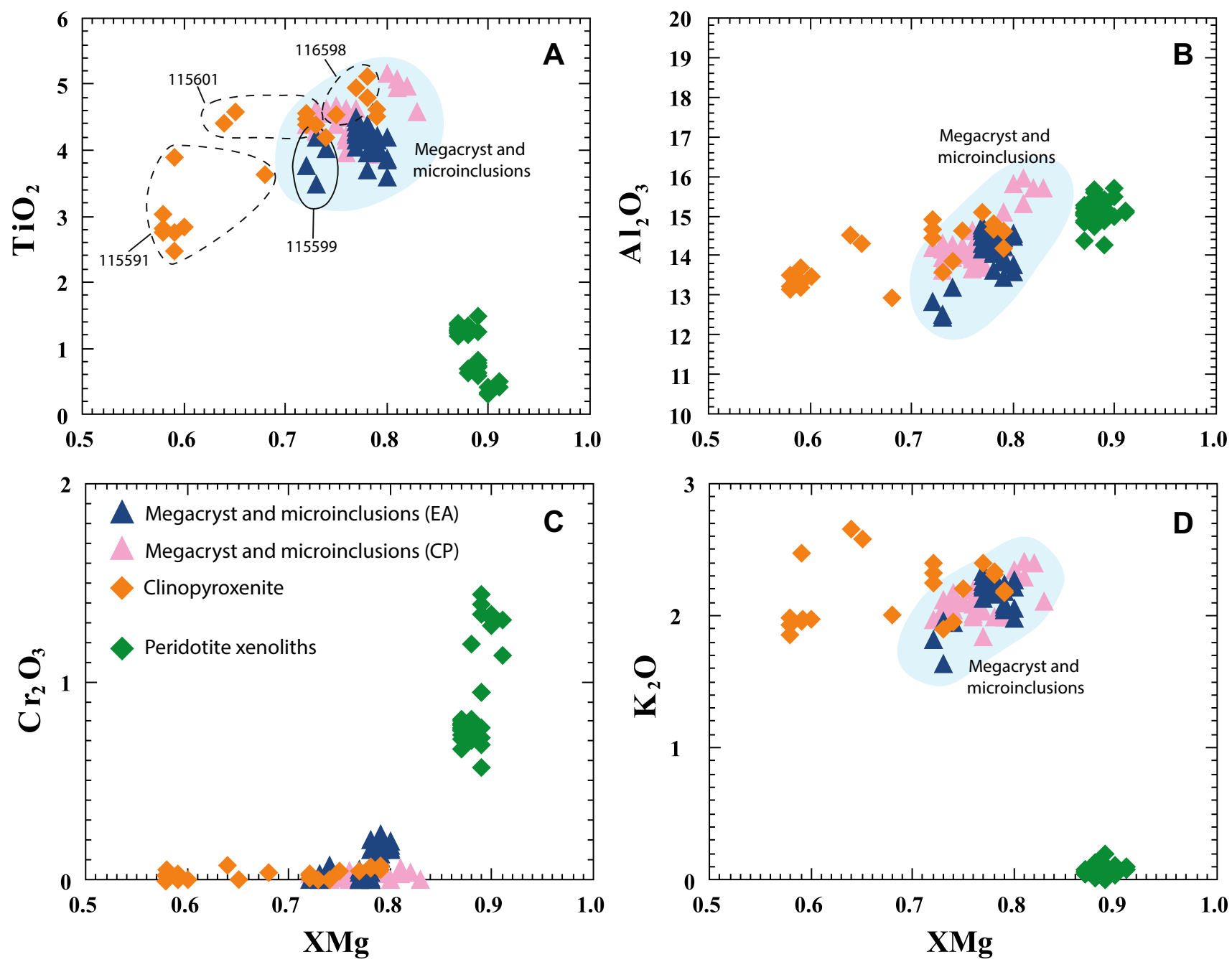

Fig. 8 Representative diagrams of major element composition of amphiboles from the El Aprisco and Cerro Pelado volcanoes. XMg is the Mgnumber. Amphibole analyses from peridotite xenoliths are taken from Villaseca et al. (2010) and González-Jiménez et al. (2014)

\subsection{Phlogopite}

The major element composition of phlogopite megacrysts, macrocrysts and microinclusions from Cerro Pelado (Table 4), defines a relatively compact group with a moderate chemical variation (Fig. 9). These phlogopites exhibit a fairly primitive composition, with $\mathrm{Mg} \#$ ranging mostly from 0.85 to 0.78 , and high $\mathrm{Al}_{2} \mathrm{O}_{3}$ (15.6-17.4 wt\%), $\mathrm{TiO}_{2}$ (4.4-6.5 wt\%) and $\mathrm{K}_{2} \mathrm{O}(7.5-10 \mathrm{wt} \%)$ concentrations. $\mathrm{Cr}_{2} \mathrm{O}_{3}$ contents are lower than $0.2 \mathrm{wt} \%$ in all cases (Fig. 9c). The close resemblance in major element composition between microinclusions and larger crystals (megacrysts and macrocrysts) (Table 4) suggests that they share a common origin.

It is also remarkable the similarity in composition of the above phlogopites with respect to those from clinopyroxenite and glimmerite enclaves found in both volcanoes (Fig. 9). The only significant distinction is the trend to a more evolved composition of phlogopites from the enclaves, with $\mathrm{Mg} \#$ ranging from 0.83 to 0.71 . Most elements do not experience a significant modification of their concentration with differentiation, except for a subtle decrease in $\mathrm{Al}_{2} \mathrm{O}_{3}$ and $\mathrm{K}_{2} \mathrm{O}$ (Fig. 9b).

Phlogopite from peridotitic xenoliths from the Cerro Pelado volcano has $\mathrm{Mg \#}$ values close to some rim composition of phlogopite microinclusions within amphibole megacrysts (e.g., Fig. 9a, b; Table 4, sample 114404). However, significant differences exist for the main oxides, such as lower $\mathrm{TiO}_{2}$, and higher $\mathrm{Cr}_{2} \mathrm{O}_{3}, \mathrm{SiO}_{2}$ and $\mathrm{Al}_{2} \mathrm{O}_{3}$ contents shown by metasomatic phlogopite in mantle xenoliths (Fig. 9). On the other hand, the composition of groundmass mica from the Calatrava volcanic rocks (Cebriá 1992) differs markedly in their higher $\mathrm{TiO}_{2}$ and lower $\mathrm{Mg \#}$ and $\mathrm{Al}_{2} \mathrm{O}_{3}$ contents (Fig. 9). 


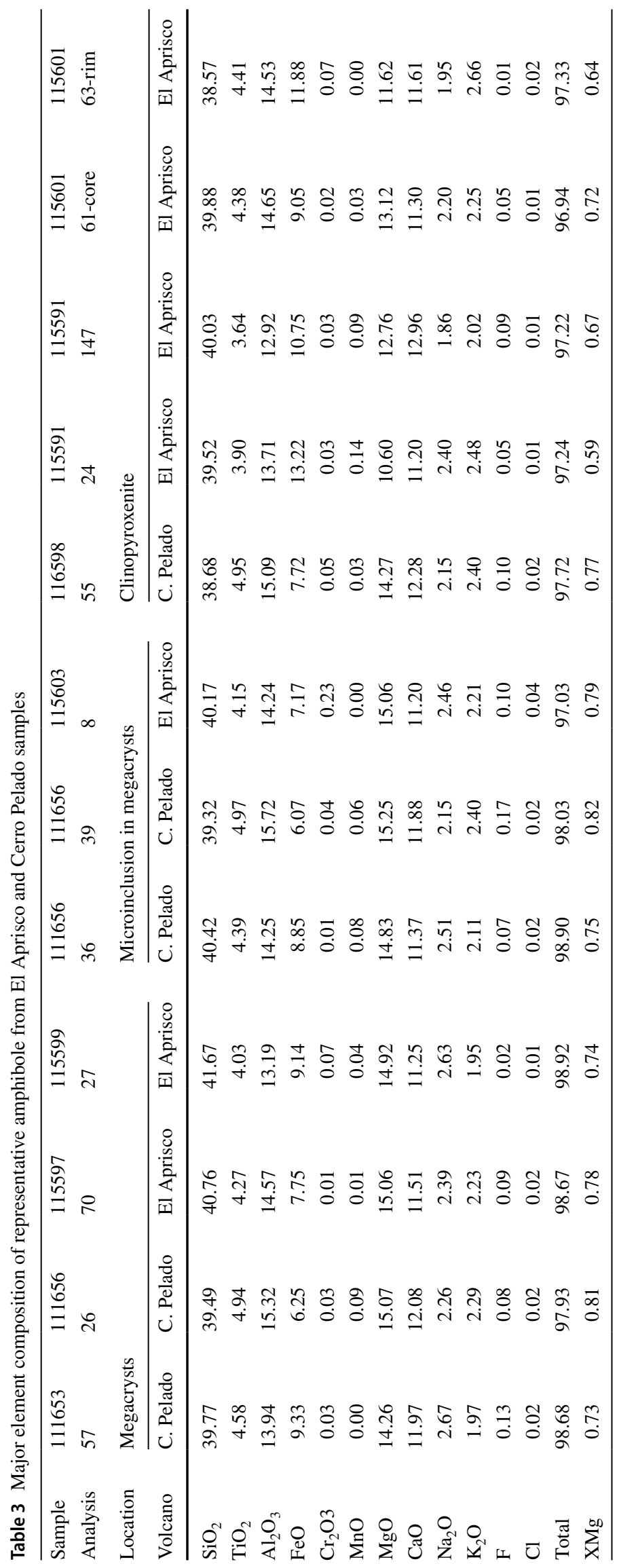


Table 4 Major element composition of representative phlogopite from El Aprisco and Cerro Pelado samples

\begin{tabular}{|c|c|c|c|c|c|c|c|c|c|c|}
\hline Sample & 114403 & 114403 & 110852 & 111654 & 114404 & 114404 & 111643 & $\begin{array}{l}65287 \\
12\end{array}$ & 115601 & 115592 \\
\hline Analysis & 1 & 8 & 65 & 70 & 91 core & $92 \mathrm{rim}$ & 51 & 12 & 54 & 34 \\
\hline \multirow[b]{2}{*}{ Volcano } & \multicolumn{2}{|l|}{ Megacryst } & \multicolumn{4}{|l|}{ Inclusion $^{\mathrm{a}}$} & Phenocryst & Glimmerite & \multicolumn{2}{|c|}{ Clinopyroxenite } \\
\hline & C. Pelado & C. Pelado & C. Pelado & C. Pelado & El Aprisco & El Aprisco & C. Pelado & C. Pelado & El Aprisco & El Aprisco \\
\hline $\mathrm{SiO}_{2}$ & 36.44 & 36.63 & 36.48 & 35.93 & 36.15 & 36.62 & 35.80 & 36.63 & 35.70 & 36.24 \\
\hline $\mathrm{TiO}_{2}$ & 6.04 & 5.77 & 5.63 & 6.38 & 4.83 & 5.38 & 5.84 & 5.86 & 5.58 & 6.38 \\
\hline $\mathrm{Al}_{2} \mathrm{O}_{3}$ & 17.03 & 17.12 & 16.11 & 16.73 & 16.67 & 17.70 & 17.02 & 16.55 & 16.19 & 16.76 \\
\hline $\mathrm{Cr}_{2} \mathrm{O}_{3}$ & 0.07 & 0.00 & 0.00 & 0.00 & 0.03 & 0.12 & 0.11 & 0.09 & 0.04 & 0.11 \\
\hline $\mathrm{FeO}$ & 7.33 & 7.71 & 8.52 & 7.68 & 6.67 & 4.10 & 7.09 & 6.75 & 9.86 & 7.45 \\
\hline $\mathrm{MnO}$ & 0.05 & 0.04 & 0.04 & 0.05 & 0.00 & 0.03 & 0.04 & 0.01 & 0.00 & 0.06 \\
\hline $\mathrm{MgO}$ & 19.18 & 18.97 & 18.61 & 18.47 & 19.31 & 20.16 & 18.32 & 18.80 & 17.23 & 18.24 \\
\hline $\mathrm{CaO}$ & 0.03 & 0.03 & 0.02 & 0.07 & 0.03 & 0.09 & bdl & 0.08 & 0.09 & 0.03 \\
\hline $\mathrm{Na}_{2} \mathrm{O}$ & 0.67 & 0.67 & 0.12 & 0.17 & 0.68 & 0.66 & 0.69 & 0.68 & 0.59 & 0.62 \\
\hline $\mathrm{K}_{2} \mathrm{O}$ & 9.08 & 9.24 & 9.97 & 9.67 & 9.02 & 9.63 & 9.17 & 9.46 & 8.55 & 9.67 \\
\hline $\mathrm{F}$ & 0.17 & 0.12 & 0.19 & 0.19 & nd & nd & 0.07 & 0.11 & 0.10 & 0.21 \\
\hline $\mathrm{Cl}$ & 0.01 & 0.00 & 0.03 & 0.01 & nd & nd & 0.03 & 0.03 & 0.02 & 0.02 \\
\hline Total & 96.10 & 96.30 & 95.72 & 95.34 & 93.37 & 94.49 & 94.28 & 95.04 & 93.95 & 95.79 \\
\hline $\mathrm{XMg}$ & 0.82 & 0.81 & 0.80 & 0.79 & 0.81 & 0.90 & 0.82 & 0.83 & 0.76 & 0.81 \\
\hline
\end{tabular}

$n d$ not determined, $b d l$ below detection limits

${ }^{\text {a } I n c l u s i o n ~ i n ~ a m p h i b o l e ~ m e g a c r y s t s ~}$

\subsection{Fe-Ti-rich minerals}

Accessory magnetite (likely pseudomorphosed to hematite; $\mathrm{FeO}$ up to $82 \mathrm{wt} \%$ ) (Table 5 analysis 111656-53) and Timagnetite are present as large anhedral to euhedral crystals, elongated rods up to $1.5 \mathrm{~mm}$ in size and microinclusions (Table 5, 115597-72) within clinopyroxene and amphibole megacrysts and clinopyroxenite enclaves (Table 5, 11560168). These megacrysts can also show aligned Ni-rich pyrrhotite micro-inclusions (exsolutions?) $(\mathrm{NiO}=3.1 \mathrm{wt} \%$, Table 5, sample 111639-25), similarly to pyrrhotite found in glimmerite enclaves from Cerro Pelado (Table 5). Accessory ilmenite and titanite are common in clinopyroxenite and glimmerite enclaves from El Aprisco maar, and ilmenite also appear in some melt blobs within amphibole megacrsyts. In all cases ilmenite has a high $\mathrm{MgO}$ content (up to $6.6 \mathrm{wt} \%$ ), similar to that described in other clinopyroxenites (e.g., Bondi et al. 2002).

\section{P-T conditions}

\subsection{Clinopyroxene thermobarometry}

Quantitative pressure and temperature estimates were obtained using the clinopyroxene-liquid barometric and thermometric equations of Neave and Putirka (2017) and
Putirka (2008), respectively. We have used the CAL-73 olivine nephelinite from Cerro Pelado and an averaged composition of olivine melilitites of the CVF (Cebriá 1992) as parental liquid compositions, due to the absence of analyzed samples from the El Aprisco volcano. We consider that clinopyroxene crystals with $\mathrm{K}_{\mathrm{D}}(\mathrm{Fe}-\mathrm{Mg})^{\text {Cpx-melt }}$ values within the interval of $0.31-0.49$ could be close to equilibrium (Table 6). Experiments with low-alkali glasses (see Fig. $1 b$ in Pilet et al. 2010) have shown that this $K_{D}$ varies as a function of the total alkali content of the coexisting melt $\left(0.3-0.4\right.$ in melts with $\mathrm{Na}_{2} \mathrm{O}+\mathrm{K}_{2} \mathrm{O}<4.5 \mathrm{wt} \%$, as in the studied rocks). Some exchange values further from equilibrium are those calculated for rims around megacrysts and phenocrysts (Table 6 and Supplementary Table 1), although they point to a polybaric decompression path of the studied volcanic rocks (Fig. 10).

Estimated temperature and pressure in clinopyroxene megacrysts yielded the following ranges: $1348-1365{ }^{\circ} \mathrm{C}$ and 14.1-15.3 kbar in Cerro Pelado and $1348-1393{ }^{\circ} \mathrm{C}$ and 14.7-16.9 kbar in El Aprisco (Table 6). These values overlap the $\mathrm{P}-\mathrm{T}$ estimates from clinopyroxene phenocryst cores calculated in both volcanos $\left(1321-1366{ }^{\circ} \mathrm{C}\right.$ and $11.9-15.5$ kbar in Cerro Pelado and $1325-1387^{\circ} \mathrm{C}$ and $12.6-17.1 \mathrm{kbar}$ in El Aprisco) (Table 6, Fig. 10). Clinopyroxene microcrystals found inside amphibole megacrysts also show similar $\mathrm{P}-\mathrm{T}$ values to those of megacrysts and phenocryst cores. On the other hand, $\mathrm{P}-\mathrm{T}$ estimates in phenocryst rims and 

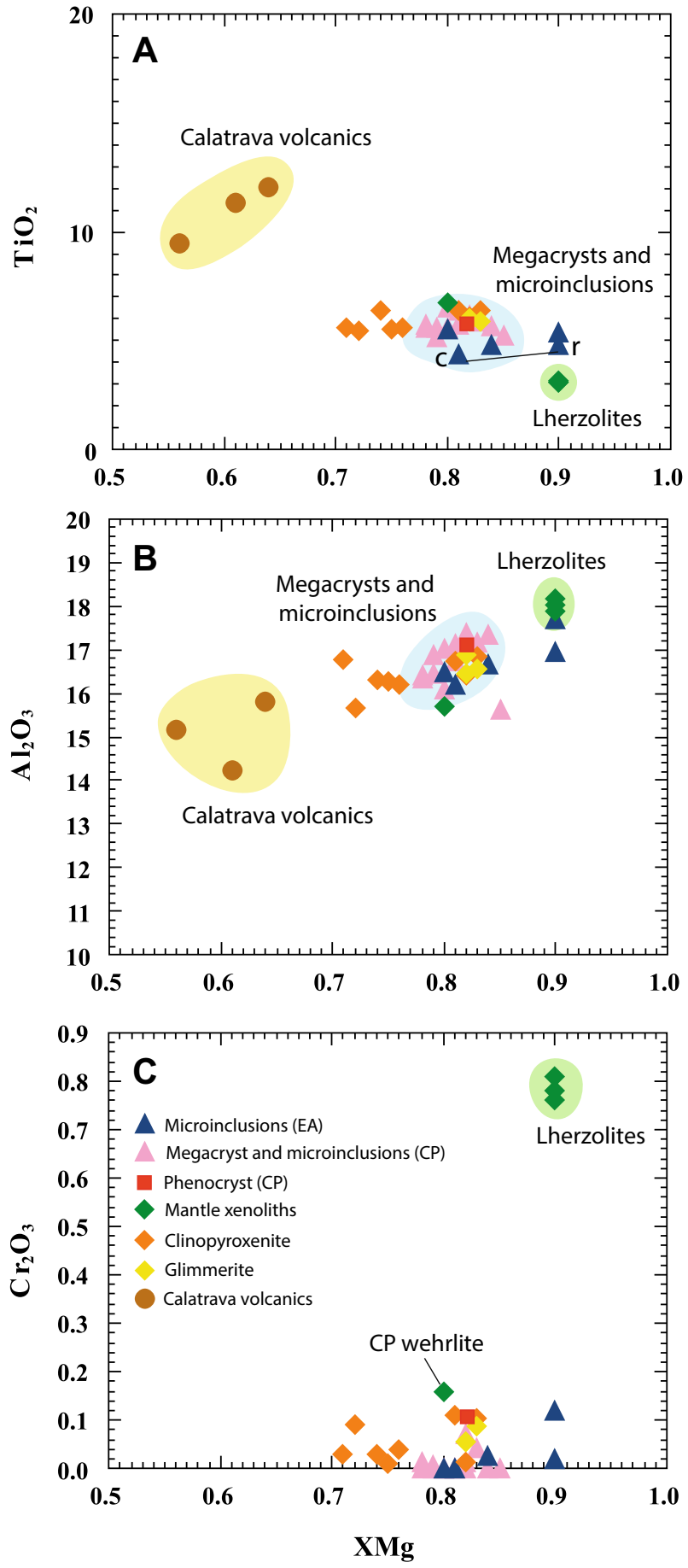

Fig. 9 Representative diagrams of major element composition of phlogopites from the El Aprisco and Cerro Pelado volcanoes. Arrow in A marks core-to-rim zoning of a phlogopite microinclusion in amphibole megacryst 114404 (see Table 4). XMg is the Mg-number. Mica analyses from groundmass of Calatrava volcanic rocks are taken from Cebriá (1992) and metasomatic phlogopite in lherzolite xenoliths (including wehrlite 72674 from the Cerro Pelado) after Villaseca et al. (2010) microcrystals of reaction zones show progressive lower temperatures $\left(\sim 1180-1270{ }^{\circ} \mathrm{C}\right)$ and pressures (3.1-8.4 kbar) (Fig. 10). The estimated temperatures of crystallization of clinopyroxene megacrysts $\left(1275-1350{ }^{\circ} \mathrm{C}\right)$ are higher than those obtained in some experimental studies on silica-undersaturated alkaline basic magmas (e.g., Irving and Green 2008; Bonechi et al. 2017). Nonetheless, Calatrava volcanic rocks are lower in $\mathrm{SiO}_{2}$ and display slightly higher $\mathrm{Mg \#}$ with respect to the experimental runs. Near liquidus amphibole and phlogopite crystallization occurs in hydrous alkaline magmas $\left(\mathrm{H}_{2} \mathrm{O} \geq 2 \mathrm{wt} \%\right)$, thus reaching temperatures in excess of $1100^{\circ} \mathrm{C}$ at $15 \mathrm{kbar}$ (Irving and Green 2008).

$P-T$ estimates in clinopyroxene cores from clinopyroxenite and glimmerite enclaves range from 11.9 to $16.5 \mathrm{kbar}$ and 1360 to $1245^{\circ} \mathrm{C}$ (Table 6 and Supplementary Table 1). The maximum pressure value has been obtained for a green clinopyroxene (intermediate sector of a zoned crystal) of enclave 115601 (Table 6) (Fig. 3b). These results are very similar to those provided by megacrysts and phenocryst cores (Table 6; Fig. 10). The rims of zoned clinopyroxenes from these enclaves display a widespread range of temperature and pressure values connecting the field of the higher pressure megacrysts with the shallower rims: up to $1245^{\circ} \mathrm{C}$ and 8.4 kbar.

The clinopyroxene geothermobarometry estimates on lherzolite xenoliths sampled by the Cerro Pelado and El Aprisco volcanoes (Villaseca et al. 2010) exhibit an almost identical pressure range to that estimated on megacrysts + phenocryst cores + clinopyroxenite enclaves, though significantly at lower temperatures (Fig. 10). Other mantle and lower crustal xenolith fragments carried by ultrabasic volcanics generated in an equivalent geodynamic context (French Massif Central; Yoshikawa et al. 2010 and references therein), reproduce a similar pattern to that observed in the CVZ (Fig. 10).

\subsection{Amphibole barometry}

Pressure estimations based on the amphibole major element composition have been calculated using the P1A and P1D barometers of Ridolfi and Renzulli (2012) (Table 6). Both calculations provide a similar range of pressures for megacrysts from Cerro Pelado, roughly from 10.3 to $17.5 \mathrm{kbar}$. Estimates for the El Aprisco volcano overlap with the above results (P1D barometer) or are slightly higher (10.2-18.3 kbar; P1A barometer). Amphibole microinclusions in other megacrysts show similar pressure values when compared to those of megacrysts (Table 6).

Amphiboles from clinopyroxenite xenoliths yield pressure estimates well within the megacrysts ranges: 11.7-17.9 kbar (P1A) and 12.1-15.2 kbar (P1D) in Cerro Pelado, and 9.4-14.9 kbar (P1A) and 10.3-16.5 (P1D) in El Aprisco. 
Table 5 Major element composition of representative Ti-magnetite, pyrrhotite, ilmenite and titanite from the El Aprisco and Cerro Pelado samples

\begin{tabular}{|c|c|c|c|c|c|c|c|c|c|c|}
\hline Sample & 115601 & 115597 & 111656 & 65287 & 111639 & 115591 & 115591 & 115599 & 115591 & 115591 \\
\hline Analysis & 68 & 72 & 53 & 15 & 25 & 17 & 22 & 28 & 23 & 19 \\
\hline \multirow[t]{2}{*}{ Mineral } & \multicolumn{2}{|c|}{ Ti-magnetite } & Hematite & Pyrrhotite & Pyrr. exsol. ${ }^{b}$ & \multicolumn{3}{|l|}{ llmenite } & \multicolumn{2}{|l|}{ Titanite } \\
\hline & Clpxenite $^{a}$ & Megacryst & Megacryst & Glimmerite & Megacryst & Clinopyrc & renite & Melt blob & Clinopy & renite \\
\hline Volcano & Aprisco & Aprisco & C. Pelado & C. Pelado & C. Pelado & Aprisco & Aprisco & Aprisco & Aprisco & Aprisco \\
\hline $\mathrm{SiO}_{2}$ & 0.26 & 1.28 & 0.86 & 0.02 & 0.00 & 0.01 & 0.00 & 0.10 & 30.36 & 30.02 \\
\hline $\mathrm{TiO}_{2}$ & 19.27 & 16.38 & 0.03 & 0.02 & 0.05 & 50.67 & 47.12 & 48.36 & 38.62 & 38.18 \\
\hline $\mathrm{Al}_{2} \mathrm{O}_{3}$ & 7.88 & 7.02 & 1.81 & 0.02 & 0.20 & 0.55 & 0.55 & 2.29 & 1.17 & 1.17 \\
\hline $\mathrm{FeO}$ & 57.48 & 57.87 & 82.00 & 71.99 & 67.78 & 41.79 & 46.44 & 40.00 & 0.74 & 0.69 \\
\hline $\mathrm{Cr}_{2} \mathrm{O}_{3}$ & 0.09 & 0.03 & 0.00 & 0.00 & 0.00 & 0.04 & 0.02 & 0.04 & 0.03 & 0.02 \\
\hline $\mathrm{MnO}$ & 0.07 & 0.08 & 0.23 & 0.00 & 0.07 & 0.28 & 0.23 & 0.04 & 0.05 & 0.06 \\
\hline $\mathrm{MgO}$ & 9.29 & 11.71 & 1.22 & 0.00 & 0.00 & 6.00 & 3.69 & 6.55 & 0.00 & 0.00 \\
\hline $\mathrm{CaO}$ & 0.45 & 0.93 & 0.05 & 0.01 & 0.19 & 0.19 & 0.04 & 0.08 & 29.36 & 29.47 \\
\hline $\mathrm{Na}_{2} \mathrm{O}$ & 0.00 & 0.08 & 0.00 & 0.00 & 0.00 & 0.02 & 0.04 & 0.00 & 0.04 & 0.01 \\
\hline $\mathrm{K}_{2} \mathrm{O}$ & 0.01 & 0.04 & 0.03 & 0.01 & 0.00 & - & 0.02 & 0.01 & 0.00 & 0.02 \\
\hline $\mathrm{NiO}$ & 0.07 & 0.10 & 0.50 & 3.74 & 3.12 & 0.03 & 0.05 & 0.09 & 0.01 & 0.00 \\
\hline $\mathrm{P}_{2} \mathrm{O}_{5}$ & 0.00 & 0.00 & 0.00 & 0.00 & 0.00 & 0.00 & 0.02 & 0.00 & 0.25 & 0.28 \\
\hline Total & 94.86 & 95.51 & 86.72 & 75.80 & 71.40 & 99.58 & 98.19 & 98.19 & 100.67 & 99.96 \\
\hline
\end{tabular}

${ }^{a}$ Clinopyroxenite enclave

${ }^{b}$ Pyrrhotite exsolved

In summary, pressure estimates obtained using clinopyroxene and amphibole barometry are fairly similar when phenocryst cores, megacrysts and clinopyroxenites phases are used, providing a main range of 10-17 kbar, although a scarce number of data expand the spectrum to higher and lower values ( 8.4 and $18.3 \mathrm{kbar}$ ). These numbers imply stagnation of silica-undersaturated alkaline basic melts within the uppermost mantle $(\sim 35-60 \mathrm{~km})$.

\section{Discussion}

\subsection{Origin of megacrysts}

The origin of large crystals in silica-undersaturated magmas is controversial, and could be either xenocrystic (i.e., mantle-derived) or phenocrystic/antecrystic (i.e., meltderived). Xenocrystic mafic megacrysts could be derived from fragmentation of mantle wall-rock xenoliths whereas melt-derived megacrysts could be either i) fragments of mantellic cumulates of different melt batches or ii) minerals crystallized in high pressure conditions, evacuated by the same magma that drove their crystallization in deep chambers or by a cogenetic fraction (e.g., Shaw and Eyzaguirre 2000; Gernon et al. 2016). The subhedral shape and large size of CVF hydrous mafic megacrysts (several cm) (Fig. 2a) contrasts strongly with the mm-size of equivalent mantle minerals (small anhedral and interstitial metasomatic crystals), thus making unlikely the possibility of their being fragments neither of mantle xenoliths transported by the basaltic magmas or from the surrounding wall-rocks. The chemistry of the studied megacrysts also differs from that of the same phases in the CVF metasomatized peridotitic xenoliths. The major element contents of these megacrysts indicate a higher degree of differentiation (lower $\mathrm{Mg} \#$ and $\mathrm{Cr}_{2} \mathrm{O}_{3}$, and higher $\mathrm{TiO}_{2}$ values) when compared to the mantle phases (Figs. 5, 8 and 9). The marked contrast in the $\mathrm{K}$ and Ti contents of amphibole (higher in megacrysts) (Fig. 8a, d) is illustrative of these differences and clearly disconnects the origin of megacrysts from the highly veined or metasomatized peridotite samples.

High-pressure experiments on alkaline basic magmas have indicated that clinopyroxene, amphibole and phlogopite megacrysts are near-liquidus phases in the upper mantle and lower crust levels (e.g., Green and Hibberson 1970; Bultitude and Green 1971; Wilkinson 1975). Clinopyroxene-melt $\mathrm{Fe}-\mathrm{Mg}$ equilibrium has been constrained by experimental observations on a diverse group of basic magmas, yielding an average $\mathrm{K}_{\mathrm{D}}(\mathrm{Fe}-\mathrm{Mg})^{C p x-l i q}=0.28 \pm 0.08$, with a slight temperature dependency (Putirka 2008). Taking into account that $\mathrm{K}_{\mathrm{D}}(\mathrm{Fe}-\mathrm{Mg})^{C p x-l i q}=\left(\mathrm{FeO}_{\text {min }} \times \mathrm{MgO}_{\text {liq }}\right) /$ $\left(\mathrm{FeO}_{\text {liq }} \times \mathrm{MgO}_{\text {min }}\right)$, the $\mathrm{Mg} \#$ of the melt in equilibrium can 
Table 6 Estimated $P-T$ conditions of megacrysts and clinopyroxenitic cumulates from El Aprisco and Cerro Pelado volcanoes

\begin{tabular}{|c|c|c|c|c|c|c|}
\hline & & $\mathrm{P}_{1 \mathrm{~A}}(\mathrm{kbar})$ & $\mathrm{P}_{1 \mathrm{D}}(\mathrm{kbar})$ & $\mathrm{P}$ (kbar) & $\mathrm{T}\left({ }^{\circ} \mathrm{C}\right)$ & $\begin{array}{l}\mathrm{K}_{\mathrm{D}}(\mathrm{Fe}- \\
\mathrm{Mg})^{\mathrm{cpx}-\mathrm{liq}}\end{array}$ \\
\hline & & \multicolumn{2}{|c|}{$\begin{array}{l}\text { Amphibole (Ridolfi } \\
\text { and Renzulli 2012) }\end{array}$} & \multicolumn{3}{|c|}{$\begin{array}{l}\text { Clinopyroxene (Neave and } \\
\text { Putirka 2017) }\end{array}$} \\
\hline \multicolumn{7}{|l|}{ El Aprisco } \\
\hline 114404 & Megacryst & 16.8 & 15.6 & 16.8 & 1378 & 0.45 \\
\hline \multirow[t]{2}{*}{ Megacrysts } & Reactional & & & 12.8 & 1318 & 0.39 \\
\hline & Inclusion & & & 15.6 & 1359 & 0.40 \\
\hline 115603 & Megacryst & & & 14.7 & 1348 & 0.42 \\
\hline \multirow[t]{3}{*}{ Megacryst } & Megacryst & 16.5 & 14.7 & 16.9 & 1393 & 0.41 \\
\hline & Reactional & & & 4.3 & 1184 & 0.49 \\
\hline & Inclusion & 19.0 & 15.6 & & & \\
\hline \multirow[t]{2}{*}{ Host melilitite } & Pheno-Core & & & 16.0 & 1373 & 0.38 \\
\hline & Pheno-Rim & & & 6.7 & 1222 & 0.70 \\
\hline 115599 & Megacryst & 11.1 & 13.5 & & & \\
\hline \multirow[t]{2}{*}{ Megacryst and host melilitite } & Microcr. & & & 2.5 & 1185 & 0.42 \\
\hline & Microcr. & & & 6.4 & 1221 & 0.66 \\
\hline 115598 & Megacryst & 15.1 & 14.7 & & & \\
\hline \multirow[t]{3}{*}{ Megacryst and host melilitite } & Pheno-Core & & & 12.6 & 1325 & 0.36 \\
\hline & Pheno-Rim & & & 5.7 & 1207 & 0.49 \\
\hline & Coronitic & 16.4 & 15.8 & 6.9 & 1213 & 0.71 \\
\hline 115604 & Megacryst & 12.5 & 13.3 & & & \\
\hline \multirow[t]{2}{*}{115597} & Megacryst & 15.3 & 15.2 & & & \\
\hline & & 13.5 & 13.9 & & & \\
\hline 115605 & Pheno-Core & & & 17.1 & 1387 & 0.38 \\
\hline \multirow[t]{3}{*}{ Host melilitite } & Pheno-Med & & & 16.5 & 1386 & 0.33 \\
\hline & Pheno-Rim & & & 6.9 & 1219 & 0.63 \\
\hline & Spongy & & & 10.1 & 1273 & 0.31 \\
\hline 115601 & & 12.6 & 13.1 & 11.9 & 1325 & 0.41 \\
\hline \multirow[t]{2}{*}{ Clinopiroxenite } & Green cpx & & & 16.5 & 1338 & 1.04 \\
\hline & & 10.5 & 11.5 & & & \\
\hline 115591 & Green cpx & 14.0 & 15.4 & 15.6 & 1326 & 0.87 \\
\hline Clinopyroxenite & & & & 16.0 & 1329 & 0.85 \\
\hline 115592 & Clinopyroxenite & & & 14.3 & 1351 & 0.37 \\
\hline \multicolumn{7}{|l|}{ Cerro Pelado } \\
\hline 110852 & Megacryst & 14.0 & 14.4 & & & \\
\hline Megacryst & Patchy & 11.3 & 12.1 & & & \\
\hline 111653 & Megacryst & 12.9 & 14.0 & & & \\
\hline 111654 & Megacryst & 14.0 & 14.4 & & & \\
\hline 111655 & Megacryst & 16.0 & 15.7 & & & \\
\hline \multirow[t]{2}{*}{ Megacryst } & Reactional & & & 6.8 & 1245 & 0.41 \\
\hline & Inclusion & 7.3 & 7.1 & & & \\
\hline 111656 & Megacryst & 14.3 & 13.9 & & & \\
\hline \multirow[t]{2}{*}{ Megacryst } & & & & 12.5 & 1324 & 0.36 \\
\hline & Inclusion & 13.7 & 13.2 & & & \\
\hline 111639 & Megacryst & & & 15.3 & 1365 & 0.35 \\
\hline Megacryst & & & & 14.1 & 1348 & 0.38 \\
\hline 114403 & Pheno-Core & & & 11.9 & 1321 & 0.30 \\
\hline Nephelinite & Pheno-Rim & & & 4.9 & 1197 & 0.81 \\
\hline 116596 & Pheno-Core & & & 15.2 & 1366 & 0.35 \\
\hline \multirow[t]{2}{*}{ Nephelinite } & Pheno-Core & & & 14.8 & 1350 & 0.39 \\
\hline & Pheno-Core green & & & 14.0 & 1321 & 1.24 \\
\hline
\end{tabular}


Table 6 (continued)

\begin{tabular}{lllllll}
\hline & & $\mathrm{P}_{1 \mathrm{~A}}(\mathrm{kbar})$ & $\mathrm{P}_{1 \mathrm{D}}(\mathrm{kbar})$ & $\mathrm{P}(\mathrm{kbar})$ & $\mathrm{T}\left({ }^{\circ} \mathrm{C}\right)$ & $\begin{array}{l}\mathrm{K}_{\mathrm{D}}(\mathrm{Fe}- \\
\mathrm{Mg})^{\mathrm{cpx}-\text { liq }}\end{array}$ \\
& & $\begin{array}{c}\text { Amphibole (Ridolfi } \\
\text { and Renzulli 2012) }\end{array}$ & \multicolumn{2}{c}{$\begin{array}{l}\text { Clinopyroxene (Neave and } \\
\text { Putirka 2017) }\end{array}$} \\
\hline & Pheno-Med & & 6.4 & 1220 & 0.53 \\
& Pheno-Rim & & 5.8 & 1217 & 0.66 \\
& Spongy & & & 6.1 & 1204 & 0.64 \\
116598 & Core & 12.9 & 14.2 & 11.8 & 1297 & 0.30 \\
Clinopyroxenite & Medium (green) & & & 14.9 & 1339 & 0.53 \\
& Medium & & & 13.0 & 1311 & 0.44 \\
65287 & Rim & & & 9.2 & 1265 & 0.42 \\
Glimmerite & Core & & & 15.2 & 1352 & 0.40 \\
\hline & Rim & & & 9.7 & 1286 & 0.36 \\
\hline
\end{tabular}

$\mathrm{K}_{\mathrm{D}}{ }^{\mathrm{cpx}-\mathrm{liq}}$ in italic are values out of standard equilibrium conditions (see text for further explanation)

Fig. $10 \mathrm{P}-\mathrm{T}$ data obtained using thermometer (equation 33) of Putirka (2008) and the barometer of Neave and Putirka (2017), based on clinopyroxene composition and clinopyroxene-liquid equilibria. Core (c)-to-rim (r) composition of phenocryst 115603

(Table 6) is shown by an arrow. The field of $P-T$ conditions of peridotite xenoliths from the French Massif Central and the CVF are taken, respectively, from Yoshikawa et al. (2010) and Villaseca et al. (2010). The Moho in central Spain is located at approximately $32 \mathrm{~km}$ depth (Granja Bruña et al. 2015), but in central France is slightly thinner $(\sim 28 \mathrm{~km}$, Yoshikawa et al. 2010 and references therein)

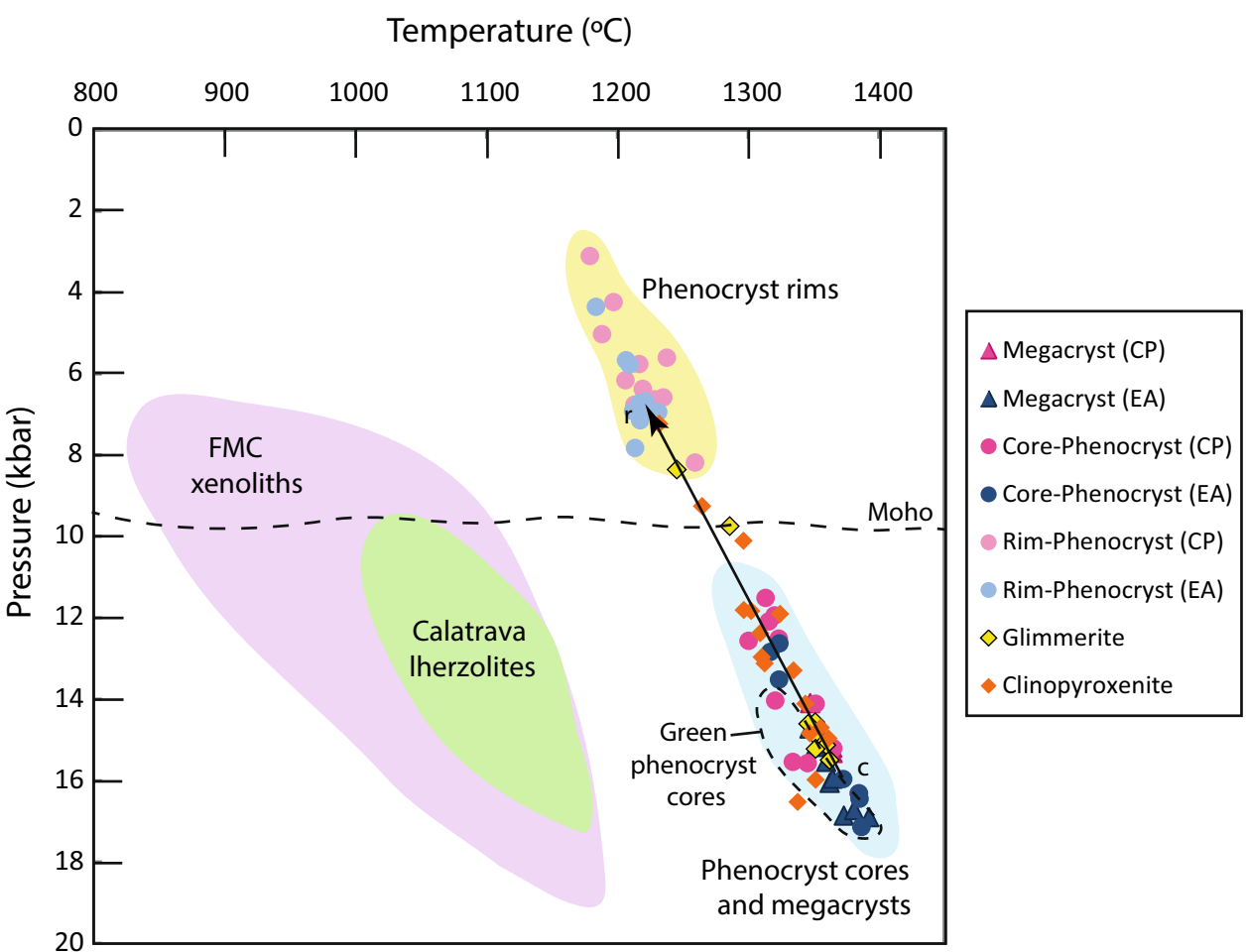

be calculated from clinopyroxene composition. We have used a $\mathrm{K}_{\mathrm{D}}(\mathrm{Fe}-\mathrm{Mg})^{C p x-l i q}=0.39$, based on melt composition from experimental data (Fig. 1b of Pilet et al. 2010) and considering the correction suggested by Putirka (2008) for a temperature of $1350{ }^{\circ} \mathrm{C}$ (see T estimates in Fig. 10). The $\mathrm{Mg \#}$ calculated for the melt in equilibrium with colourless clinopyroxene megacrysts $(\mathrm{Mg} \#=0.81-0.83)$ is in the range $0.66-0.62$. These values are slightly lower than the wholerock data provided for El Aprisco magmas (0.80-0.75; Lierenfeld and Mattsson 2015) but within the compositional range of most CVF melilitites and nephelinites (0.75-0.62; Cebriá and López Ruiz 1995). These results would imply near equilibrium conditions between these clinopyroxene megacrysts and the host magmas, but the existence of reaction textures and rims indicates a more complex scenario (Fig. 3a, b). Moreover, the presence of a high volume of mafic phenocrysts in the sampled volcanic rocks, showing strong chemical zoning (Fig. 7), likely indicates that whole-rock chemistry represents an average composition, influenced both by the host melt and the phenocrysts cargo carried from deep-seated magma chambers, as previously described in studies focused on antecrysts-laden basic magmas (e.g., Ubide et al. 2014; Sun et al. 2018). Even though the application of the above formula is not straightforward 
for amphibole and phlogopite, as their $\mathrm{Fe}^{2+} / \mathrm{Fe}^{3+}$ ratios are not known, the fact that all mafic megacrysts display broadly coincident Mg\# ranges ( 0.85-0.73) strongly supports that mafic megacrysts crystallized close to equilibrium from primitive melts similar to those of the El Aprisco and Cerro Pelado volcanic rocks.

The high Mg\# of megacrysts evidences crystallization from ultrabasic primitive melts and the calculated $\mathrm{Mg \#}$ for the melt $(0.66)$ supports a near primary signature. The chemical composition of clinopyroxene, amphibole and phlogopite megacrysts display a moderate heterogeneity, with a general increase of $\mathrm{FeO}, \mathrm{TiO}_{2}$ and $\mathrm{CaO}$ and a depletion of $\mathrm{MgO}, \mathrm{Cr}_{2} \mathrm{O}_{3}$ and $\mathrm{K}_{2} \mathrm{O}$ contents from core to rim (Figs. 5, $8,9)$, in accordance with fractional crystallization of these mafic phases from evolving magma batches, in the absence of plagioclase (e.g., Cebriá 1992; Mattsson et al. 2013). Mg\# and $\mathrm{NiO}$ contents in olivine macrocrysts and phenocrysts may reach values as high as those of olivine in peridotites (Fig. 4), but are also variable and display a moderate to strong decrease $(\mathrm{Mg} \#=0.9-0.85, \mathrm{NiO}=0.48-0.04 \mathrm{wt} \%)$. The slightly less primitive composition observed in small euhedral olivine phenocrysts, combined with core to rim normal zoning, preclude a xenocrystic origin for them. $\mathrm{Mg \#}$ in olivine is only slightly higher than that of clinopyroxene, amphibole and phlogopite megacrysts. Fe-Mg equilibrium between olivine and melt $\left(\mathrm{K}_{\mathrm{D}}=0.3\right.$; Roeder and Emslie 1970) provide Mg\# (melt) values in the range 0.73-0.63. These numbers are higher than those calculated for the megacrysts, but would agree with the early crystallization of olivine from a similar primitive magma within deep-seated mantle magma reservoirs.

It is interesting to note that the colourless cores of clinopyroxene phenocrysts of the host volcanic rocks exhibit an overlapping composition with respect to megacrysts, and follow a similar evolution trend (Fig. 5). This feature suggests a genetic connection between both types of crystals. Moreover, the existence of clinopyroxene phenocrysts with green cores, which present a contrasted composition with respect to colourless cores and the groundmass crystals (Fig. 5), reveals a complex magmatic story, which is described in more detail in the section below.

\subsection{Origin of pyroxenite and glimmerite enclaves}

There are several textural and chemical features of the CVF clinopyroxenite and glimmerite enclaves which do not support their origin as mantle fragments. While minerals in peridotites and metasomatic veins are usually unzoned and very homogeneous with regards to their major element composition (e.g., Villaseca et al. 2010; Lustrino et al. 2016), clinopyroxene and amphibole of the studied mafic enclaves display sector or oscillatory zoning (Fig. 3e, f), which is a typical igneous texture. Clinopyroxene from these enclaves never shows narrow orthopyroxene exsolution lamellae, as commonly occurs in peridotite pyroxenes. The lack of protogranular or crystalloblastic textures and deformation twins, common in peridotite xenoliths, also contradicts the derivation of the pyroxenite enclaves by entrapment of wallrock mantle portions within the ascending basic magma.

A key argument favoring the magmatic origin of the CVF pyroxenite and glimmerite enclaves is the chemical composition of their mafic phases. They do not show $\mathrm{Mg} \#$ as high as the mantle minerals $(<0.85$; Figs. $5,8,9)$ and their major element contents are fairly variable, reaching a moderate degree of evolution (e.g., $\mathrm{Mg} \#$ in cpx decreases to 0.64 ; Fig. 5). The fact that the chemical composition of the main mafic minerals of these enclaves (clinopyroxene, amphibole and phlogopite) overlaps that of megacrysts and some phenocryst cores dispersed within the host volcanic magma (Figs. 5, 8, 9), is a clear indication that they all share a magmatic origin and crystallized from similar cogenetic basic melts.

The oscillatory zoning of clinopyroxene from the studied ultramafic enclaves provides the most relevant information to understand the chemical evolution of the deep-seated basic magma, as it displays a wide compositional range (e.g., $\mathrm{Mg} \#=0.8-0.65$ in a single crystal; clinopyroxenite enclave 115601 , Table 2). Core composition of clinopyroxene is usually primitive (Mg\# 0.8-0.83) and similar to that of megacrysts and colourless phenocrysts (e.g. Fig. 5b spot C2). The only exception is enclave 115591, whose pale green clinopyroxene is very homogeneous and more differentiated (Fig. 5). The core to rim evolution is broadly characterized

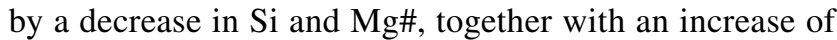
$\mathrm{Al}, \mathrm{Ti}$ and $\mathrm{Na}$. Nonetheless, slight to moderate oscillations in this evolution can produce the reverse pattern, indicative of occasional magma rejuvenation (Fig. 6). This chemical zoning also reflects the coexistence of pale green and colourless clinopyroxene of variable $\mathrm{Mg \#} \mathrm{(e.g.,} \mathrm{about} 0.65$ for the green zones and 0.82 for the colourless core) in the same textural microdomain within clinopyroxenite cumulates, and would be in accordance with the fractionation of clinopyroxene and amphibole in hydrous melilitite melts. Olivine, though scarce, has been found in one phlogopite-bearing clinopyroxenite enclave (115592). The three phases in this xenolith have similar $\mathrm{Mg \#}(0.81-0.85)$, which is indicative of equilibrium and also suggests that olivine, although early in the crystallization sequence, can be considered cogenetic with the cumulates and megacrysts.

Clinopyroxene from enclave 115591 does not show oscillatory zoning, but a homogeneous composition only modified in its most external rim (Fig. 6c), where melt infiltrated the enclave and a microcrystalline matrix of skeletal olivine, pale purple clinopyroxene, titanite, ilmenite and glass is present. This rim composition is rich in $\mathrm{Al}, \mathrm{Ti}$ and $\mathrm{Ca}$, and depleted in Si and Na (Figs. 5, 6), displaying a composition 
similar to that of purple rims from clinopyroxene phenocrysts, either with green or colourless cores (Fig. 7), and likely crystallized from the host melt. Thus, while the main zoning pattern present in clinopyroxene from most clinopyroxenites is associated with the evolution of a magma fractionating at depth, the Ti-Al-rich and $\mathrm{Si}-\mathrm{Na}$-poor rims were generated en-route by interaction with the host melilititic/ nephelinitic melt. The lower Si and Na concentrations of these latter rims are likely related with their crystallization at lower pressures (e.g., Putirka 2008).

Taking into account the textural and chemical features of the studied rocks, both green and colourless clinopyroxene phenocryst cores can be considered antecrysts. The former would have been in equilibrium with a more evolved, highly fractionated melt, than the near-liquidus melt that gave rise to colourless cores. It is significant that both antecryst types display an overlapping major element composition, or very close, to that of clinopyroxene from the ultramafic enclaves (Fig. 5). This similitude reinforces the genetic connection of megacrysts, phenocryst cores and pyroxenites, and supports that they all belong to the same magmatic system and followed a similar fractionation process from melts close in composition. Clinopyroxene composition depicts a continuous evolution trend from the most primitive megacrysts/colourless phenocrysts to the evolved green phenocrysts cores, with the heterogeneous composition of clinopyroxene from enclaves filling the gap (Fig. 5). This differentiation process might have started with olivine fractionation, but was rapidly dominated by clinopyroxene and amphibole crystallization, inducing the observed decrease in $\mathrm{Mg} \#$ and $\mathrm{Si}$ (also reflected in zoning patterns). However, the drop of $\mathrm{Ti}$ and $\mathrm{Al}$ contents towards the green clinopyroxene field (Fig. 5) evidences that phlogopite is subsequently added as a main fractionating phase. This process could also explain the subtle decrease in $\mathrm{K}$ experienced by the most evolved amphiboles (Fig. 8d). The presence of glimmerite enclaves ( $>90 \%$ phlogopite) can be taken as an evidence of the role played by phlogopite during differentiation, and also points to the cumulate nature of these enclaves. The evolution trend described above can hardly fit with the low $\mathrm{Ti}$ and $\mathrm{Al}$ composition of the pale green cpx from clinopyroxenite 115591, as well as with that of the green antecryst cores found by Lierenfeld and Mattsson (2015) (Fig. 5a, b). These cumulates from the El Aprisco maar deposits evidence that differentiation, though controlled by similar phases, likely occurred independently in several CVF magma chambers.

Megacrysts, phenocrysts cores and mafic enclaves can be considered crystal cumulates fractionating at shallow lithospheric mantle levels, as deduced from the geothermobarometric data (Fig. 10). This is in agreement with the statement that kaersutitic amphibole, which is only present as megacryst or within enclaves, is a typical mineral of high $\mathrm{P}-\mathrm{T}$, low- $\mathrm{H}_{2} \mathrm{O}$ (mixed $\mathrm{CO}_{2}-\mathrm{H}_{2} \mathrm{O}$ volatile) conditions in alkaline magmas as summarized by Ridolfi and Renzulli (2012), and never crystallizes in lavas or pyroclastic deposits. The coexistence of a variable clinopyroxene crystal population (green and colourless phenocryst cores), whose compositional range is also recorded within oscillatory-zoned crystals from clinopyroxenite enclaves, points to crystallization from silica-undersaturated magmas with a variable degree of evolution. Nevertheless, the connection of the extreme clinopyroxene compositional poles through a single evolution trend might suggest that they share a common primary melt. Studies focused on other circum-Mediterranean Cenozoic volcanic fields, showing a similar dichotomy in the type of clinopyroxene phenocryst cores, have estimated differences in the fractionation rate up to $70 \%$ between melts forming green and colourless clinopyroxenes, but derived from the same magmatic system (Jankovics et al. 2016). The future acquisition of trace element data on clinopyroxene will contribute to better constrain these aspects.

\subsection{Level of extraction of mafic megacrysts and enclaves}

The chemical similitude between the clinopyroxene of phenocryst cores, megacrysts and clinopyroxenites strengthens the idea that all these large ( $\mathrm{mm}$ to $\mathrm{cm}$ in size) mafic crystals are derived from similar magmas. Geothermometrical estimations based on clinopyroxene-melt equilibrium (e.g., Putirka 2008), are in the range $1302-1370{ }^{\circ} \mathrm{C}$ for megacrysts, phenocrysts and enclaves, while slightly lower values $\left(1225^{\circ} \mathrm{C}\right)$ have been obtained for reaction and rim clinopyroxenes (Table 6), in accordance with the deeper origin of the former group of clinopyroxenes. These values are slightly higher than experimental results on silica-undersaturated alkaline basic magmas (Irving and Green 2008). Given that studied volcanics are ultrabasic melts, another consideration is the difficulty in obtaining an appropriate melt composition, as the available whole-rock data is highly porphyritic (mixture of crystals and melt) and likely biased towards a more primitive composition, which yields higher temperature estimates.

Pressure estimates obtained using the geobarometers of Ridolfi and Renzulli (2012) and Neave and Putirka (2017) are broadly equivalent and mainly restricted to a $P$ range from 11.7 to $16.8 \mathrm{kbar}$ (Table 6). The overlapping of values derived from these three barometers (two for amphibole and one for clinopyroxene) give consistency to our results, and suggests that the parental magmas of megacrysts, phenocryst cores and clinopyroxenites stagnated in magma chambers located at lithospheric mantle depths (at about $47 \pm 13 \mathrm{~km}$ ) (Fig. 10). The similitude with pressures calculated for the accompanying CVF mantle peridotites also supports this conclusion. Only clinopyroxenes from reaction zones and phenocrysts rims provide much lower pressures (3.1-8.4 
kbar), in agreement with their entrapment and late crystallization during magma ascent and eruption.

The above pressure estimates are coherent with the presence of olivine macrocrysts in the host melilitite/nephelinite melts. In fact, this mineral can provide an approximate constrain to the maximum possible pressure of crystallization, as its stability field has been determined experimentally to reach around $15 \mathrm{kbar}$ in some silica-undersaturated alkaline basic magmas, with a drastic reduction above that value (e.g., Irving and Green 2008). On the contrary, at that pressure conditions, amphibole, phlogopite and clinopyroxene control fractional crystallization of hydrous alkaline basic magmas (Pilet et al. 2010; Irving and Green 2008).

\subsection{Model of megacryst and mafic cumulates formation in the CVF volcanics}

Geochemical features of the CVF magmas point to their derivation from a metasomatized asthenospheric mantle source (Cebriá and López Ruiz 1995). Our geobarometric estimations imply stagnation of these melts in shallower levels, within the lithospheric mantle. Pressure calculations in the deep-seated materials (e.g., megacrysts and enclaves) provide a wide range (10.5-17.1 kbar), equivalent to depths about 33-60 km. Although a complex system of magma reservoirs could be envisaged (Fig. 11), with crystal fractionation occurring at different levels, the above pressure range has to be taken with caution. The differences in pressure estimated within single zoned clinopyroxene crystals (euhedral oscillatory zoning) demonstrate that they may be artificial and caused by uncertainty in the melt composition used for the calculation (bulk-rock analyses), that also ignores the chemical evolution of the melt. The estimated $\mathrm{P}-\mathrm{T}$ conditions likely provide a rough approximation to the depth of stagnation, as deviations of up to 4 kbar may result from the use of uncorrected bulk-rock compositions (Sun et al. 2018), thus making unnecessary a melt percolation model through stepped magma chambers at different depths within the upper mantle.

The stagnated melts would start to crystallize once the liquidus conditions were reached, giving rise to the formation of a mineral mush layer where larger crystals (up to $\mathrm{cm}$ ) would become megacrysts and the smaller ones would derive in phenocrysts. Intermittent infiltration of the more primitive surrounding melt within the crystal mush, could explain the common oscillatory zoning in clinopyroxene of pyroxenite enclaves. The ongoing crystallization, and possible compaction of the crystal set in the chamber margins, would lead to formation of ultramafic cumulates, mainly constituted by clinopyroxene \pm amphibole \pm phlogopite. The wide spectrum of primitive to relatively evolved mineral compositions observed in just one clinopyroxenite enclave suggests that most pyroxenites could have been formed within a crystallization front (Marsh 1996), where interstitial melt can evolve independently and to a higher degree from the inward magma. The melilitite/nephelinite melt concentrated in the inner part
Fig. 11 Schematic cartoon illustrating the mantle-crustal structure beneath the Calatrava volcanic field and the magmatic plumbing system explained in the text. $M$ megacryst, $P h$ phenocryst, $E_{c p x}$ clinopyroxenite enclave, $X_{m+l}$ mantle (peridotite) xenolith. Formation of $\mathrm{CO}_{2}$ bubbles (empty circles in figure) by carbonic exsolution within host magma has been schematized (see text for further explanation). Mineral abbreviations after Kretz (1983)

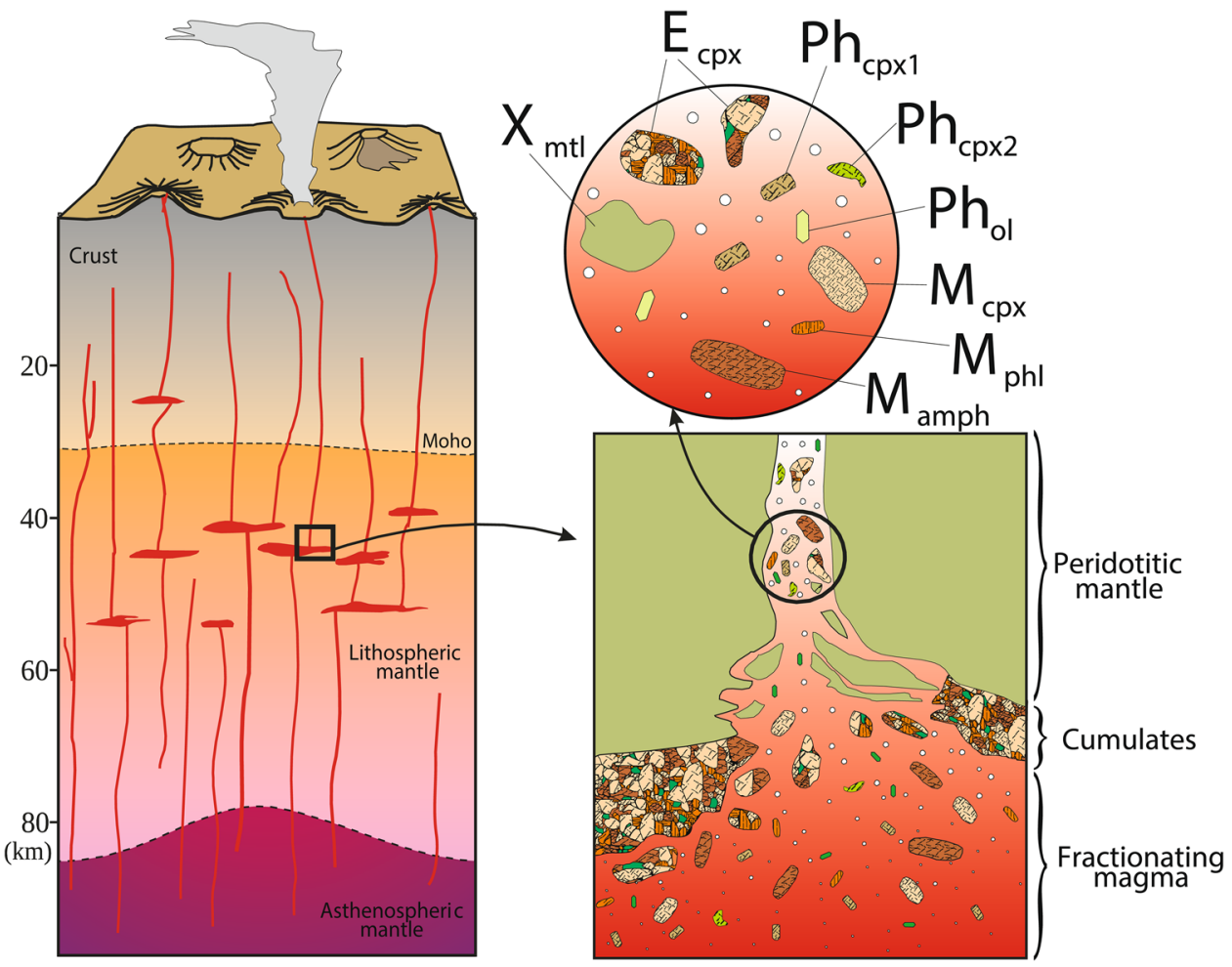


of the chamber would likely be less differentiated than that of the outer mineral carapace, but it would still have evolved with respect to the initial parental magma. The extraction of this evolving melt prior to eruption would lead to the transport of the heterogeneous crystal cargo (xenoliths, pyroxenites, antecrysts) to shallower levels, where purple clinopyroxenes (including phenocryst rims) would crystallize. Nevertheless, mixing with melts ascending from different sources (open magmatic system) cannot be completely discarded to explain the complexity of magmatic systems operating in the CVF.

Hydrous minerals would be near liquidus phases, as determined for silica-undersaturated basic alkaline magmas (e.g., Irving and Green 2008). Their crystallization could increase the relative activity of $\mathrm{CO}_{2}$ in the magma volatile budget, thus favoring the possibility of a boiling process at shallow mantle depths due to the low grade of solubility of this volatile compound. The possibility of melt fragmentation at mantle depth was proposed by Bailey (1985) for $\mathrm{CO}_{2}$-rich magmas and has also been advocated in studies focused on the alkaline volcanics of the CVF (Stoppa et al. 2012). This $\mathrm{CO}_{2}$ exsolution can induce high velocity eruption and ascension as a partially fluidized melt (Lloyd and Stoppa 2003). If this first boiling happened, hydraulic fracturing of the surrounding rocks would have occurred, and then, the rising melt could have eroded and scavenged the marginal crystalline layer of the chamber (cumulate minerals) together with the local peridotite wall-rocks, when moving towards the surface (Fig. 11). Later volatile exsolution related to decompression during magma ascent likely contributed to the generation of these mixed magmas by adding crustal crystals and rock fragments.

The complex suite of juvenile fractionates (megacrysts and phenocrysts of different sizes and nature, along with a variety of clinopyroxene- or phlogopite-rich cumulate aggregates) and mantle xenoliths, to which new crustal fragments were added during its rapid evacuation towards the surface, appear dispersed within the pyroclastic deposits of El Aprisco and the Cerro Pelado centers. Differences in $\mathrm{CO}_{2}$ contents between melilitite and nephelinite magmas from these volcanoes could explain the different degree of magmatic fragmentation and eruptive behavior leading to a maar-diatreme eruption in the case of El Aprisco center, whereas a strombolian plume activity was developed in the Cerro Pelado volcano. The participation of subsequent phreatomagmatic fragmentation in the El Aprisco maar is also probable as stated by Lierenfeld and Mattsson (2015).

\section{Conclusions}

We have undertaken the first detailed study on the mineral chemistry of phenocrysts, megacrysts and clinopyroxenite and glimmerite enclaves carried by alkaline rocks of the
Calatrava volcanic field. We have sampled clinopyroxene, amphibole and phlogopite megacrysts that appear in the unusual crystal-rich and xenolith-rich pyroclastic rocks of the Cerro Pelado scoria cone and the El Aprisco maar. The mafic megacrysts display a chemical composition similar to the same phases in clinopyroxenite enclaves and rare phlogopite-rich (glimmerite) clinopyroxenites. The heterogeneous composition of megacrysts, macrocrysts and phenocrysts, together with their textural features, suggest that they all share a magmatic origin. Nevertheless, the presence of disequilibrium textures and contrasting compositions (including reverse zoning) in clinopyroxene crystals indicate that they did not crystallize from a unique melt. The crystal-melt $\mathrm{Fe}-\mathrm{Mg}$ partitioning estimated for olivine and clinopyroxene imply that these cumulates were near in equilibrium with the host magma, and crystallized within magma chambers prior to their entrapment. The evolution in clinopyroxene major element composition supports a fractionation process mainly controlled by clinopyroxene, amphibole and phlogopite crystallization.

Megacrysts, phenocryst cores and enclaves represent high-P cumulates mostly formed at about $12-16 \mathrm{kbar}$, slightly below the boundary between the lower crust and the upper lithospheric mantle ( 35 to $55 \mathrm{~km}$ ). The estimated high temperatures of crystallization of megacrsyts and phenocryst cores $\left(1350-1275{ }^{\circ} \mathrm{C}\right)$ and rims $\left(1260-1180{ }^{\circ} \mathrm{C}\right)$ suggest low water or mixed $\mathrm{CO}_{2}-\mathrm{H}_{2} \mathrm{O}$ contents in the melt. The wide spectrum of primitive to relatively evolved mineral compositions observed in the enclaves agrees with their formation in a crystallization front, where interstitial melt can evolve independently from the inward magma. The crystallization of hydrous mafic minerals at mantle depths could have facilitated $\mathrm{CO}_{2}$ exsolution and subsequent boiling of the alkaline magma, thus triggering the fragmentation of the semi-crystallized mush margin of the magma chamber and the excavation of mantle wall-rocks. This deep fragmentation and later volatile exsolution during ascent through the mantle lithosphere could explain the complex variety of crystals, enclaves and xenoliths dragged by the volcanic magmas.

Clinopyroxene is the most common and widespread phase, occurring as megacryst, macrocryst and phenocryst in these volcanic rocks. Two types of high-P crystals of different colour (green and colourless) are observed in some of the studied samples, the green ones having low $\mathrm{Mg} \#$ indicative of their derivation from much more fractionated melts than the primitive colourless cores of high $\mathrm{Mg \#}$. The coexistence and complex zoning in some crystals of clinopyroxenites suggest that colourless and green types might be cognate, being crystallized as early and late fractionates from petrogenetically related magmas. This study illustrates that deep magmatic systems beneath monogenetic volcanic fields are complex, involving several stages of melt generation, 
accumulation, fractionation and contamination at variable depths. Moreover, the present study provides a model for the ascent of crystal- and xenolith-rich magmas beneath the CVF of central Spain that might be considered in other alkaline volcanics carrying complex crystal cargos, as commonly observed in the Cenozoic volcanism of the circumMediterranean area.

Acknowledgements We acknowledge Alfredo Fernández Larios for his assistance with the electron microprobe in the Centro Nacional de Microscopía Electrónica Luis Bru (UCM). We thank associate editor Teresa Ubide and the two reviewers Marco Brenna and Mario Gaeta for their helpful comments on an earlier version of this paper. This work is included in the objectives of, and supported by, the CGL2016-78796 project of the Ministerio de Economía y Competitividad de España, and the 910492 UCM project.

\section{References}

Allègre, C. J., \& Turcotte, D. L. (1986). Implications of a two-component marble-cake mantle. Nature, 323, 123-127.

Ancochea, E. (1982). Evolución espacial y temporal del volcanismo reciente de España Central. Doctoral Thesis, Universidad Complutense de Madrid.

Ancochea, E. (2004). La región volcánica del Campo de Calatrava. In J. A. Vera (Ed.), Geología de España (pp. 676-677). Madrid: SGE-IGME

Ancochea, E., \& Nixon, P. H. (1987). Xenoliths in the Iberian Peninsula. In P. H. Nixon (Ed.), Mantle xenoliths (pp. 119-124). Chichester: Wiley.

Andía, J. R. (2017). Caracterización de los xenolitos peridotíticos del volcán Los Tormos (Pozuelo de Calatrava, Ciudad Real) (pp. 49). Master thesis, Universidad Complutense.

Andía, J., Villaseca, C., \& Pérez-Soba, C. (2018). Mineralogical characterization of peridotite xenoliths from the Los Tormos volcano (Calatrava volcanic field). Geogaceta, 63, 99-102.

Bailey, D. K. (1985). Fluids, melts, flowage, and styles of eruption in alkaline-ultra-alkaline magmatism. Transactions of the Geological Society of South Africa, 88, 449-457.

Bodinier, J. L., Guiraud, M., Fabries, J., Dostal, J., \& Dupuy, C. (1987). Petrogenesis of layered pyroxenites from the Lherz, Freychinede and Prades ultramafic bodies (Ariege, French Pyrenees). Geochimica et Cosmochimica Acta, 51, 279-290.

Bondi, M., Morten, L., Nimis, P., Rossi, P. L., \& Tranne, C. A. (2002). Megacrysts and mafic-ultramafic xenolith-bearing ignimbrites from Sirwa Volcano, Morocco: phase petrology and thermobarometry. Mineralogy and Petrology, 75, 203-221.

Bonechi, B., Perinelli, C., Gaeta, M., Tecchiato, V., \& Granati, S. F. (2017). Experimental constraints on amphibole stability in primary alkaline and calc-alkaline magmas. Periodico di Mineralogia, 86, 231-245.

Bultitude, R. J., \& Green, D. H. (1971). Experimental study of crystalliquid relationships at high pressure in olivine nephelinite and basanite compositions. Journal of Petrology, 12, 121-147.

Bussweiler, Y., Foley, S. F., Prelevic, D., \& Jacob, D. E. (2015). The olivine macrocryst problem: new insights from minor and trace element compositions of olivine from Lac de Gras kimberlites, Canada. Lithos, 220-223, 238-352.

Carminati, E., Lustrino, M., \& Doglioni, C. (2012). Geodynamic evolution of the central and western Mediterranean: tectonics vs. igneous petrology constraints. Tectonophysics, 579, 173-192.
Cebriá, J. M. (1992). Geoquímica de las rocas basálticas y leucititas de la region volcánicas de Campo de Calatrava, España (pp. 341). Doctoral Thesis, Universidad Complutense de Madrid.

Cebriá, J. M., \& López Ruiz, J. (1995). Alkali basalts and leucitites in an extensional intracontinental plate setting: the late Cenozoic Calatrava volcanic province (central Spain). Lithos, 35, 27-46.

Cebriá, J. M., Martín-Escorza, C., López-Ruiz, J., Morán-Zenteno, D. J., \& Martiny, B. M. (2011). Numerical recognition of alignments in monogenetic volcanic areas: examples from the MichoacánGuanajato Volcanic Field in Mexico and Calatrava in Spain. Journal of Volcanology and Geothermal Research, 201, 73-82.

De Vicente, G., \& Vegas, R. (2009). Large-scale distributed deformation controlled topography along the western Africa-Eurasia limit: tectonic constraints. Tectonophysics, 474, 124-143.

Dorado, O., Villaseca, C., \& Orejana, D. (2016). Geoquímica de los megacristales de los volcanes de El Aprisco y Cerro Pelado (Campo de Calatrava). Macla, 21, 29-31.

Downes, H. (2007). Origin and significance of spinel and garnet pyroxenites in the shallow lithospheric mantle: Ultramafic massifs in orogenic belts in Western Europe and NW Africa. Lithos, 99, $1-24$.

Galán, G., Domenech, M., Oliveras, V., \& Fernández-Roig, M. (2017). Megacrystals and related xenoliths in basaltic lavas from the San Corneli Volcano (Girona, NE Spain). Macla, 22, 45-46.

Garrido, C. J., \& Bodinier, J. L. (1999). Diversity of mafic rocks in the Ronda Peridotite; evidence for pervasive melt-rock reaction during heating subcontinental lithosphere by upwelling asthenosphere. Journal of Petrology, 40, 729-754.

Gernon, T. M., Upton, B. G. J., Ugra, R., Yücel, C., Taylor, R. N., \& Elliott, H. (2016). Complex subvolcanic magma plumbing system of an alkali basaltic maar-diatreme volcano (Elie Ness, Fife, Scotland). Lithos, 264, 70-85.

González-Jiménez, J. M., Villaseca, C., Griffin, W. I., O’Reilly, S. Y., Belousova, E., Ancochea, E., et al. (2014). Significance of ancient sulfide PGE and Re-Os signatures in the mantle beneath Calatrava, Central Spain. Contribution to Mineralogy and Petrology, 168,1047

Granet, M., Wilson, M., \& Achauer, U. (1995). Imaging a mantle plume beneath the French Massif Central. Earth Planet Science Letters, 136, 281-296.

Granja Bruña, J. L., Vegas, R., Sentre, M. A., Muñoz-Martín, A., \& Sainz-Maza, S. (2015). Gravity modeling of the lithosphere in the Calatrava Volcanic Province (Spain): geodynamic implications. Journal of Iberian Geology, 41, 233-252.

Green, D. H., \& Hibberson, W. (1970). Experimental duplication of conditions of precipitation of high pressure phenocrysts in a basaltic magma. Physics of the Earth and Planetary Interiors, 3, 247-254.

Herrero-Hernández, A., López-Moro, F., Gallardo-Millán, J. L., Martín-Serrano, A., \& Gómez-Fernández, F. (2015). Volcanismsedimentation interaction in the Campo de Calatrava Volcanic Field (Spain): a magnetostratigraphic and geochronological study. International Journal of Earth Sciences, 104, 103-122.

Irving, A. J., \& Frey, F. A. (1984). Trace element abundances in megacrysts and their host basalts; constraints on partition coefficients and megacryst genesis. Geochimica et Cosmochimica Acta, 48, $1201-1221$.

Irving, A. J., \& Green, D. H. (2008). Phase relationships of hydrous alkalic magmas at high pressures: production of nepheline hawaiitic to mugearitic liquids by amphibole-dominated fractional crystallization within the lithospheric mantle. Journal of Petrology, 49, 741-756.

Jankovics, M. E., Taracsák, Z., Dobosi, G., Embey-Isztin, A., Batki, A., Harangi, S., et al. (2016). Clinopyroxene with diverse origins in alkaline basalts from the western Pannonian Basin: Implications from trace element characteristics. Lithos, 262, 120-134. 
Kretz, R. (1983). Symbols of rock-forming minerals. American Mineralogist, 68, 277-279.

Leake, B. E., Woolley, A. R., Birch, W. D., Burke, E. A. J., Ferraris, G., Grice, J. D., et al. (2004). Nomenclature of amphiboles: additions and revisions to the International Mineralogical Association's amphibole nomenclature. Mineralogical Magazine, 68, 209-215.

Lierenfeld, M. B., \& Mattsson, H. B. (2015). Geochemistry and eruptive behaviour of the Finca la Nava maar volcano (Campo de Calatrava, south-central Spain). International Journal of Earth Sciences, 104, 1795-1817.

Lloyd, F. E., \& Stoppa, F. (2003). Pelletal lapilli in diatremes. Some inspiration from the old masters. GeoLines, 15, 65-71.

López Ruiz, J., Cebriá, J. M., Doblas, M., Oyarzun, R., Hoyos, M., \& Martín, C. (1993). The late Cenozoic alkaline volcanism of the central Iberian Peninsula (Calatrava Volcanic Province, Spain): intraplate volcanism related to extensional tectonics. Journal of the Geological Society, London, 150, 915-922.

López Ruiz, J., Cebriá, J. M., Doblas, M. (2002) Cenozoic volcanism I: the Iberian peninsula. In W. Gibbon \& T. Moreno (Eds.), The geology of Spain (pp. 417-438). London: Geological Society.

Lustrino, M., Prelevic, D., Agostini, S., Gaeta, M., Di Rocco, T., Stagno, V., et al. (2016). Ca-rich carbonates associated with ultrabasic-ultramafic melts: Carbonatite or limestone xenoliths? A case study from the late Miocene Morron de Villamayor volcano (Calatrava Volcanic Field, central Spain). Geochimica et Cosmochimica Acta, 185, 477-497.

Lustrino, M., \& Wilson, M. (2007). The circum-Mediterranean anorogenic Cenozoic igneous province. Earth Science Reviews, 81, $1-65$.

Marsh, B. D. (1996). Solidification fronts and magmatic evolution. Mineralogical Magazine, 60, 5-40.

Mattsson, H. B., Nandedkar, R. H., \& Ulmer, P. (2013). Petrogenesis of the melilititic and nephelinitic rock suites in the lake NatronEngaruka monogenetic volcanic field, northern Tanzania. Lithos, 179, 175-192.

Neave, D. A., \& Putirka, K. D. (2017). A new clinopyroxene-liquid barometer, and implications for magma storage pressures under Icelandic rift zones. American Mineralogist, 102, 777-794.

Orejana, D., Villaseca, C., \& Paterson, B. A. (2006). Geochemistry of pyroxenitic and hornblenditic xenoliths in alkaline lamprophyres from the Spanish Central System. Lithos, 86, 167-196.

Peterson, T. D., \& LeCheminant, A. N. (1993). Glimmerite xenoliths in early proterozoic ultrapotassic rocks from the Churchill province. Canadian Mineralogist, 31, 801-819.

Pilet, S., Ulmer, P., \& Villiger, S. (2010). Liquid line of descent of a basanitic liquid at $1.5 \mathrm{GPa}$ : Constraints on the formation of metasomatic veins. Contributions to Mineralogy and Petrology, $159,621-643$.

Praegel, N. O. (1981). Origin of ultramafic inclusions and megacrysts in a monchiquite dyke at Streap, Inverness-shire, Scotland. Lithos, 14, 305-322.

Putirka, K. D. (2008). Thermometers and barometers for volcanic systems. Reviews in Mineralogy and Geochemistry, 69, 61-120.

Ridolfi, F., \& Renzulli, A. (2012). Calcic amphiboles in calc-alkaline and alkaline magmas: thermobarometric empirical equations valid up to $1130{ }^{\circ} \mathrm{C}$ and $2.2 \mathrm{GPa}$. Contributions to Mineralogy and Petrology, 163, 877-895.

Roeder, P. L., \& Emslie, R. F. (1970). Olivine-liquid equilibrium. Contributions to Mineralogy and Petrology, 29, 275-289.
Shaw, C. S. J., \& Eyzaguirre, J. (2000). Origin of megacrysts in the mafic alkaline lavas of the West Eiffel volcanic field, Germany. Lithos, 50, 75-95.

Stoppa, F., Rosatelli, G., Schiazza, M., Tranquilli, A. (2012). Hydrovolcanic vs magmatic processes in forming maars and associated pyroclasts: the Calatrava-Spain-Case history. In: F. Stoppa (Ed.) Updates in volcanology - a comprehensive approach to volcanological problems (pp. 3-26). InTech. ISBN: 978-953-307-434-4.

Sun, P., Niu, Y., Guo, P., Cui, H., Ye, L., \& Liu, J. (2018). The evolution and ascent paths of mantle xenolith-bearing magma: Observations and insights from Cenozoic basalts in Southeast China. Lithos, 310-311, 171-181.

Ubide, T., Galé, C., Larrea, P., Arranz, E., \& Lago, M. (2014). Antecrysts and their effect on rock compositions: The Cretaceous lamprophyre suite in the Catalonian Coastal Ranges (NE Spain). Lithos, 206-207, 214-233.

Villaseca, C., Ancochea, E., Orejana, D., Jeffries, T. E. (2010). Composition and evolution of the lithospheric mantle in central Spain: inferences from peridotite xenoliths from the Cenozoic Calatrava volcanic field. In M. Coltorti, H., Downes, M., Grégoire, S.Y. O'Reilly (Eds.), Petrological evolution of the European Lithospheric Mantle (Vol. 337, pp. 125-151). Geological Society Special Publication.

Villaseca, C., Belousova, E., Barfod, D., \& González-Jiménez, J. M. (2019). Dating metasomatic events in the lithospheric mantle beneath the Calatrava volcanic field (central Spain). Lithosphere. https://doi.org/10.1130/L1030.1.

Wiesmaier, S., Deegan, F. M., Troll, V. R., Carracedo, J. C., Chadwick, J. P., \& Chew, D. M. (2011). Magma mixing in the 1100 AD Montaña Reventada composite lava flow, Tenerife, Canary Islands: interaction between rift zone and central volcano plumbing systems. Contributions to Mineralogy and Petrology, 162, 651-669.

Wilkinson, J. F. G. (1975). Ultramafic inclusions an high pressure megacrysts from a nephelinite sill, Nandewar Mountains, north-eastern New South Wales, and their bearing on the origin of certain ultramafic inclusions in alkaline volcanic rocks. Contributions to Mineralogy and Petrology, 51, 235-262.

Wilkinson, J. F. G., \& Stolz, A. J. (1997). Subcalcic clinopyroxenites and associated ultramafic xenoliths in alkali basalt near Glen Innes, northeastern New South Wales, Australia. Contributions to Mineralogy and Petrology, 127, 272-291.

Wilshire, H. G., \& Shervais, J. W. (1975). Al-augite and Cr-diopside ultramafic xenoliths in basaltic rocks from western United States. Physics and Chemistry of the Earth, 9, 257-272.

Witt-Eickschen, G., \& Kramm, U. (1998). Evidence for the multiple stage evolution of the subcontinental lithospheric mantle beneath the Eifel (Germany) from pyroxenite and composite pyroxenite/ peridotite xenoliths. Contributions to Mineralogy and Petrology, 131, 258-272.

Yoshikawa, M., Kawamoto, T., Shibata, T., Yamamoto, J. (2010). Geochemical and $\mathrm{Sr}-\mathrm{Nd}$ isotopic characteristics and pressuretemperature estimates of mantle xenoliths from the French Massif Central: Evidence for melting and multiple metasomatism by silicate-rich carbonatite and asthenospheric melts. In M. Coltorti, H., Downes, M., Grégoire, S. Y. O’Reilly (Eds.), Petrological evolution of the European Lithospheric Mantle (Vol. 337, pp. 153-175). London: Geological Society Special Publication. 


\section{Affiliations}

\section{Villaseca ${ }^{1,2}$ (D) O. Dorado ${ }^{1} \cdot$ D. Orejana ${ }^{1}$}

C. Villaseca

granito@ucm.es

O. Dorado

odorado@ucm.es

D. Orejana

dorejana@ucm.es
1 Dpt. Mineralogía y Petrología, Facultad CC Geológicas, UCM, 28040 Madrid, Spain

2 Instituto de Geociencias IGEO (UCM, CSIC), 28040 Madrid, Spain 